\title{
LKB1 Is Physiologically Required for Sleep from Drosophila to the Mouse
}

Ziyi Liu, ${ }^{1}$ Lifen Jiang, ${ }^{1}$ Chaoyi Li, ${ }^{2}$ Chengang Li, ${ }^{1}$ Jingqun Yang, ${ }^{1}$ Dan Wang, ${ }^{1}$ Renbo Mao, ${ }^{1}$ and Yi Rao ${ }^{1,3 *}$

${ }^{1}$ Chinese Institute for Brain Research, Beijing; Capital Medical University, PKU-

IDG/McGovern Institute for Brain Research, Peking-Tsinghua Center for Life

Sciences, Peking University School of Life Sciences, Beijing 100871, China.

${ }^{2}$ Institute of Molecular Physiology, Shenzhen Bay Laboratory, Shenzhen, Guangdong, China.

${ }^{3}$ Lead Contact

*Correspondence (email: yrao@pku.edu.cn) 
LKB1 is known as a master kinase for 14 kinases related to the adenosine monophosphate (AMP)-activated protein kinase (AMPK). Two of them (SIK3 and AMPK $\alpha$ ) have previously been implicated in sleep regulation. We generated loss-offunction (LOF) mutants for Lkb1 in both Drosophila and mice. Sleep was reduced in Lkb1-mutant flies and in flies with neuronal deletion of Lkb1. Sleep was reduced in mice after virally mediated reduction of Lkb1 in the brain. Electroencephalography (EEG) analysis showed that non-rapid eye movement (NREM) sleep and sleep need were both reduced in Lkb1-mutant mice. These results indicate that LKB1 plays a physiological role in sleep regulation conserved from flies to mice. 


\section{INTRODUCTION}

Human Peutz-Jeghers syndrome (PJS) (Jeghers et al. 1949; Peutz 1921) is an autosomal dominant disorder with gastrointestinal (GI) polyps and increased risk of multiple tissues (Tomlinson and Houlston 1997; Westerman et al. 1999). The gene mutated in, and responsible for, PJS encodes the liver kinase B1 (LKB1, also known as STK11) (Hemminki et al. 1998; Hemminki et al. 1997; Jenne et al. 1998). Lkb1 is thus a tumor suppressor gene, mutated in multiple cancers, especially the GI (Bardeesy et al. 2002; Hearle et al. 2006; Jishage et al. 2002; Mehenni et al. 1998; Miyoshi et al. 2002) and lung adenocarcinoma (Carretero et al. 2004; Gill et al. 2011; Ji et al. 2007; Matsumoto et al. 2007; Sanchez-Cespedes et al. 2002; Skoulidis et al. 2015), cervical cancer (Wingo et al. 2009), ovarian cancer (Tanwar et al. 2014), breast cancer (Hearle et al. 2006; Sengupta et al. 2017; Shen et al. 2002), pancreatic cancer (Morton et al. 2010) and melanoma (Guldberg et al. 1999; Rowan et al. 1999).

LKB1 phosphorylates threonine 172 (T172) of the $\alpha$ subunit of adenosine monophosphate (AMP)-activated protein kinase (AMPK $\alpha$ ) (Hawley et al. 2003; Hong et al. 2003; Lizcano et al. 2004; Sakamoto et al. 2005; Shaw et al. 2004; Shaw et al. 2005; Sutherland et al. 2003; Woods et al. 2003), and positively regulates the activity of AMPK.

AMPK is a well-known kinase (Beg et al. 1973; Carling et al. 1989; Carling et al. 1987; Carlson and Kim 1973; Ferrer et al. 1985; Ingebritsen et al. 1978; Munday et al. 1988; Yeh and Kim 1980) with important physiological and pathological roles (Hardie 2014; Hardie et al. 2016; Herzig and Shaw 2018; Lopez and Dieguez 2014). The $\alpha, \beta$ 
and $\gamma$ subunits of AMPK form a heterotrimeric complex (Davies et al. 1994; Michell et al. 1996; Mitchelhill et al. 1994). The catalytic $\alpha$ subunit is regulated by phosphorylation at T172 of AMPK $\alpha 2$ or T183 of AMPK $\alpha 1$ (Hawley et al. 1996).

There are 12 additional mammalian AMPK-related kinases (ARKs), similar to the $\alpha$ subunit of AMPK, all regulated at the site equivalent to AMPK-T172 (Lizcano et al. 2004). LKB1 and its associated proteins STE20-related adaptor (STRAD) and mouse protein 25 (MO25) have been reported to phosphorylate all 14 ARKs (Lizcano et al. 2004), making LKB1 a master kinase for ARKs (Alessi et al. 2006; Lizcano et al. 2004; Shackelford and Shaw 2009).

Some ARKs have been reported to regulate sleep. In mice, inhibitors of AMPK were found to decrease sleep, whereas activators of AMPK were found to increase sleep (Chikahisa et al. 2009). In flies, knockdown of AMPK $\beta$ in neurons decreased the total amount of sleep and resulted in fragmented sleep (Nagy et al. 2018). Knockdown of AMPK $\alpha$ in a specific pair of neurons suppressed sleep (Yurgel et al. 2019).

Studies in mice have shown that sleep was increased in gain-of-function (GOF) mutations in the salt inducible kinase (SIK) 3 (Funato et al. 2016), and sleep need was reduced in GOF mutants of SIK 1, 2 and 3 (Funato et al. 2016; Honda et al. 2018; Park et al. 2020). Sleep was also decreased when SIK3 was downregulated in flies (Funato et al. 2016).

Here we investigated the functional role of LKB1 in regulating sleep in flies and mice.

\section{RESULTS}




\section{Sleep Phenotypes of Lkb1 Mutant Drosophila}

Null mutants for Lkb1 are lethal in Drosophila (Martin and St Johnston 2003). We had generated a Lkb1 knockout ("lkb1 ${ }^{\mathrm{T} 1}$ ”) line (Figure S1A, S2B) and found that $1 \mathrm{~kb} 1^{\mathrm{T} 1 / \mathrm{T} 1}$ mutation was lethal in the pupa stage. The level of Lkb1 mRNA was reduced in the heterozygous $1 \mathrm{~kb}^{\mathrm{T} 1 /+}$ flies (Figure $\mathrm{S} 1 \mathrm{~B}$ ). We then tested whether the heterozygous $1 \mathrm{~kb} 1^{\mathrm{T} 1}$ had any phenotype in sleep using flies kept in 12 hours (h) light/ $12 \mathrm{~h}$ dark (LD) cycles (Figure S1C). While $1 \mathrm{~kb} 1^{\mathrm{T} 1 /+}$ flies were not significantly different from the wild type (wt) flies in sleep bout numbers (Figure S1E), or daytime sleep duration (Figure $\mathrm{S} 1 \mathrm{D})$, daytime sleep bout duration (Figure $\mathrm{S} 1 \mathrm{~F}$ ), $1 \mathrm{~kb}^{\mathrm{T} 1 /+}$ flies showed significantly lower nighttime sleep duration (Figure S1D), nighttime sleep bout duration (Figure S1F) and longer latency to sleep (Figure S1G). Thus, there was dosage-sensitive physiological requirement of Lkb1 in nighttime sleep.

We tried to, and succeeded in, generating $1 \mathrm{~kb} 1^{\mathrm{T} 2}$, a hypomorphic mutation for Lkb1 in flies (Figure 1A, S2A and S2B). Lkb1 mRNA was significantly reduced in $1 \mathrm{~kb} 1^{\mathrm{T} 2 /+}$ and $\mathrm{lkb} 1^{\mathrm{T} 2 / \mathrm{T} 2}$ flies (Figure 1B).

During the day, sleep duration was significantly less in $1 \mathrm{~kb} 1^{\mathrm{T} 2 / \mathrm{T} 2}$ flies than in $1 \mathrm{~kb} 1^{\mathrm{T} 2 /+}$ and wt flies (Figure $1 \mathrm{C}, 1 \mathrm{D}$ ), sleep bout number was significantly less in $1 \mathrm{~kb} 1^{\mathrm{T} 2 / \mathrm{T} 2}$ flies than in $1 \mathrm{~kb}^{\mathrm{T} 2 /+}$ and wt flies (Figure 1E), while sleep bout duration and latency showed no difference in three groups (Figure 1F, 1G).

During the night, not only $1 \mathrm{~kb} 1^{\mathrm{T} 2 / \mathrm{T} 2}$ flies showed highly reduced sleep duration (Figure 1C, 1D), highly reduced sleep bout number (Figure 1E), highly reduced sleep bout duration (Figure $1 \mathrm{~F}$ ) and highly increased latency (Figure $1 \mathrm{G}$ ) than the wt flies, 
but the $1 \mathrm{~kb} 1^{\mathrm{T} 2 /+}$ flies were also significantly different from the wt flies in all these parameters (Figure $1 \mathrm{C}$ to $1 \mathrm{G}$ ), confirming a dosage sensitive requirement for Lkb1.

Results of sleep analysis of $1 \mathrm{~kb} 1^{\mathrm{T} 1 /+}, 1 \mathrm{~kb} 1^{\mathrm{T} 2 /+}$ and $1 \mathrm{~kb} 1^{\mathrm{T} 2 / \mathrm{T} 2}$ mutant flies are all consistent with the possibility that Lkb1 plays a physiological role in promoting sleep.

\section{Rescue of Sleep Phenotypes by Lkb1 in Flies}

We inserted the sequence of the yeast transcription factor Gal4 into the $1 \mathrm{~kb} 1^{\mathrm{T} 2}$ mutant flies, flanking the $1 \mathrm{~kb} 1$ promoter, and obtained $1 \mathrm{~kb} 1^{\mathrm{T} 2}$-Gal4 flies (Figure $2 \mathrm{~A}$ ). We also generated UAS-Lkb1 flies in which the Lkb1 coding sequence (CDS) was expressed under the control of the upstream activation sequence (UAS). Because Gal4 protein binds to the UAS (Brand and Perrimon 1993), the expression of Lkb1 in flies resulting from the crosses between $1 \mathrm{~kb}^{\mathrm{T} 2}$-Gal4 flies and UAS-Lkb1 flies would be under the control of the endogenous Lkb1 promoter. Indeed, expression of Lkb1 mRNA was restored when $1 \mathrm{~kb}^{\mathrm{T} 2}$-Gal4 and UAS-Lkb1 were present in the same flies (Figure 2B), whereas Lkb1 mRNA was less in UAS-Lkb1; $1 \mathrm{~kb} 1^{\mathrm{T} 2 / \mathrm{T} 2}$ mutant flies, and $1 \mathrm{~kb} 1^{\mathrm{T} 2}-\mathrm{Gal} 4 /$ $1 \mathrm{~kb} 1^{\mathrm{T} 2}$-Gal4 flies than that in the wt. UAS-Lkb1 alone could not restore Lkb1 mRNA expression level to that in wt flies (Figure 2B).

Both daytime and nighttime sleep durations were less in $1 \mathrm{~kb} 1^{\mathrm{T} 2}-\mathrm{Gal} 14 \mathrm{~kb} 1^{\mathrm{T} 2}-\mathrm{Ga} 14$ flies than those in wt flies (Figure 2C). Introduction of UAS-Lkb1 in $1 \mathrm{~kb} 1^{\mathrm{T} 2 / \mathrm{T} 2}$ flies or $1 \mathrm{~kb} 1^{\mathrm{T} 2}$-Gal4 alone could not restore sleep. When both $1 \mathrm{~kb} 1^{\mathrm{T} 2}-\mathrm{Ga} 14$ and UAS-Lkb1 were present, nighttime sleep durations were restored (Figure 2D). Nighttime sleep bout number, nighttime sleep bout duration and nighttime latency were restored when both 
$1 \mathrm{~kb} 1^{\mathrm{T} 2}-\mathrm{Ga} 14$ and UAS-Lkb1 were present, but not when $1 \mathrm{~kb} 1^{\mathrm{T} 2}-\mathrm{Ga} 14$ or UAS-Lkb1 alone was present (Figure 2E, 2F and 2G).

These results support that the sleep phenotypes of $1 \mathrm{~kb} 1^{\mathrm{T} 2 / \mathrm{T} 2}$ were resulted from the reduction of Lkb1 mRNA expression in these flies.

\section{Sleep Phenotypes of Flies Carrying Neuronal Deletion of the Lkb1 Gene}

To determine whether Lkb1 functions in neurons, we used the CRISPR-Cas9 system to delete Lkb1 from neurons specifically (Figure S3). A pan-neuronal Gal4 driver (57C10Gal4) was used to control the expression of small guide RNA (sgRNA) targetting Lkb1 in neurons. Sleep was not significantly different when either 57C10-Gal4 or UAS-Lkb1 sgRNA alone was introduced into flies (Figure 3), but when both 57C10-Gal4 and UAS-Lkb1 sgRNA were present in flies, nighttime sleep duration (Figure 3B) and nighttime sleep bout duration (Figure 3D) were significantly reduced and nighttime sleep latency significantly lengthened (Figure 3E).

Daytime sleep duration, bout number, bout duration and latency were not significantly affected by neuronal gene targeting of Lkb1 (Figure 3B, 3C, 3D and 3E).

In all three series of experiments (Figures 1, 2 and 3), nighttime sleep phenotypes were more obvious than daytime sleep phenotypes. These results strongly indicate that Lkb1 expression in neurons are required physiologically for sleep, especially nighttime sleep.

\section{Sleep Phenotypes in Lkb1 Conditional Knockout Mice}


To study the involvement of Lkb1 in sleep of mammalian animals, we obtained Lkb1 $1^{\mathrm{fl} / \mathrm{fl}}$ mice in which the loxP sites flanked exons 3 to 6 of the Lkb1 gene (Nakada et al. 2010). To delete the Lkb1 gene from these mice, we injected adeno-associated viral (AAV) constructs expressing either the Cre recombinase together with the green fluorescent protein (GFP) or GFP alone to infect the mouse brain. Cre-GFP or GFP was under the control of a neuronal specific promoter hsyn (in AAV-PHP.B-hsyn-Cre-GFP or AAVPHP.B-hsyn-GFP).

We analyzed the expression of LKB1 protein in mice (Figure 4A, 4B). Injection of Cre-GFP expressing virus into wt or $\mathrm{Lkbl}^{\mathrm{fl} /+}$ mice did not reduce LKB1 protein expression in the brain. Neither did injection of only GFP expressing virus into Lkb1 $1^{\mathrm{fl} / \mathrm{fl}}$ mice. This conclusion was reached by examination of either several mouse brains combined (Figure 4A), or individual mouse brains (Figure 4B).

Functionally, only when the Cre-GFP expressing virus was injected into Lkb1 $1^{\mathrm{fl} / \mathrm{fl}}$ mice, wake duration was significantly increased during daytime (Figure 4C, S4A), nonrapid eye movement (NREM) sleep duration was significantly decreased during daytime (Figure 4E, S4B). Controls (Cre-GFP injection into wt or $\mathrm{Lkbl}^{\mathrm{fl} /+}$ mice, GFP injection into $\mathrm{Lkb1}^{\mathrm{fl} / \mathrm{fl}}$ mice) did not significantly changed any sleep phenotypes.

Rapid eye movement (REM) sleep duration was not significantly affected by CreGFP injection into Lkb1 $1^{\mathrm{fl} / \mathrm{fl}}$ mice (Figure 4G, S4C).

Power density in the $1-4 \mathrm{~Hz}$ range ( $\delta$ power density) of NREM is a commonly accepted indicator of sleep need (Borbely 1982; Borbely et al. 1981; Daan et al. 1984; Dijk et al. 1987; Franken et al. 2001; Tobler and Borbely 1986; Werth et al. 1996). We 
found that NREM $\delta$ power density was significantly reduced when the Cre-GFP expressing virus was injected into $\mathrm{Lkb} 1^{\mathrm{fl} / \mathrm{fl}}$ mice (Figure 4F). Analysis over $24 \mathrm{~h}$ indicated that significant reduction was observed over most of the daily cycle (Figure $4 I)$.

\section{Circadian Rhythm in Lkb1 Mutant Flies}

The transcription factor differentiated embryo-chondrocyte 1 (DEC1) regulates circadian rhythm and can negatively regulate the transcription of Lkb1 and subsequently reduce AMPK activity (Sato et al. 2015).

We tested whether the circadian rhythm was affected in Lkb1 mutant flies. Lkb1 mutant flies were not different from wt flies in period length (Figure S5). Relative rhythmic power was increased in $1 \mathrm{~kb} 1^{\mathrm{T} 2 /+}$ and $1 \mathrm{~kb} 1^{\mathrm{T} 2 / \mathrm{T} 2}$ mutants than wt flies. (Figure S5).

\section{DISCUSSION}

Our results indicate that LKB1 is required for sleep regulation: it plays an important and conserved role by promoting sleep in both flies and mice. LKB1 plays this role in neurons in both species because gene targeting of Lkb1 in neurons led to reduction of sleep. In mice, with the additional advantage of EEG analysis, we find that LKB1 regulates sleep need as indicated by reduced NREM $\delta$ power density in Lkb1 knockdown mutant mice. 
Sleep is important for animals. Sleep regulation is accomplished through two processes: circadian and sleep homeostatic (Borbely 1982; Borbely et al. 2016). The circadian clock regulates the timing of sleep, and homeostatic process regulates the sleep drive. Molecular mechanisms of the circadian clock have been revealed through research in Drosophila and other organisms (Allada and Chung 2010; Mohawk et al. 2012; Nitabach and Taghert 2008). Although many sleep-related genes have been identified in sleep regulation (Allada et al. 2017; Cirelli 2009; Jan et al. 2020), our understanding of the mechanisms underlying sleep homeostatic regulation remains limited (Allada et al. 2017; Donlea et al. 2017).

Multiple regions in Drosophila and mouse brains have been implicated in sleep regulation. In flies, sleep is regulated by several regions including: the ILNV and DN1 clock neurons which are important for circadian control of sleep (Chung et al. 2009; Kunst et al. 2014; Parisky et al. 2008; Shang et al. 2013; Shang et al. 2008; Sheeba et al. 2008), and the mushroom bodies (MBs), the dorsal of fan-shaped body (dFB), the ellipsoid body (EB) the pars intercerebralis (PI) and glia (Chen et al. 2015; Crocker et al. 2010; Donlea et al. 2014; Donlea et al. 2011; Foltenyi et al. 2007; Guo et al. 2011; Joiner et al. 2006; Liu et al. 2012; Liu et al. 2016; Park et al. 2014; Pimentel et al. 2016; Seugnet et al. 2011; Ueno et al. 2012; Yi et al. 2013). In mammals, sleep is regulated by monoaminergic, cholinergic, glutamatergic, and GABAergic neurons that are distributed in multiple regions including the brain stem, the preoptic hypothalamus, the lateral hypothalamus and the basal forebrain (Saper and Fuller 2017; Scammell et al. 
2017; Weber and Dan 2016). It will be interesting to investigate whether Lkb1 functions in all or a limited subset of neurons to regulate sleep.

Lkb1 as a master kinase can regulate the activities of ARKs by phosphorylating the site in the active T loop equivalent to AMPK-T172 (Lizcano et al. 2004). Because both AMPK and SIK3 are involved in sleep regulation, it will be interesting to investigate downstream kinases mediating the function of Lkb1 in sleep regulation. Is it SIK3, AMPK, or other members of the AMPK related kinases? The $\mathrm{Ca}^{2+} /$ calmodulindependent protein kinase kinase-2 (CaMKK2, also known as CaMKK $\beta$ ) could phosphorylate AMPK $\alpha-T 172$ (Anderson et al. 2008; Hawley et al. 2005; Hurley et al. 2005; Woods et al. 2005), but CaMKK2 could not phosphorylate the equivalent sites in the other AMPK related kinases, including SIK3 (Fogarty et al. 2010). It will be interesting to investigate whether and how CaMKK2 regulates sleep.

In Drosophila, LKB1 functions through SIK3 which phosphorylates histone deacetylase 4 (HDAC4) to regulate lipid storage (Choi et al. 2015). It will be interesting to investigate whether HDAC4 is downstream of LKB1 in sleep regulation.

More importantly, an important question for further studies is whether Lkb1 regulation of sleep is related to its regulation of metabolism. Changes in energy homeostasis directly and reversibly influence the sleep/wake cycle (Collet et al. 2016). Some molecules involved in metabolism regulate sleep (Bjorness and Greene 2009; Gerstner et al. 2011; Grubbs et al. 2020; Nixon et al. 2015; Taheri et al. 2004; Thimgan et al. 2010). In Drosophila, starvation suppresses sleep without building up sleep drive (Thimgan et al. 2010). Lkb1 and its downstream components are involved in regulating 
metabolism, with examples such as LKB1-AMPK signaling in the liver regulating glucose homeostasis (Shaw et al. 2005), SIK3-HDAC4 regulating energy balance in Drosophila (Wang et al. 2011). Either LKB1 has two independent roles in sleep and metabolism or that its two roles are related. 


\section{MATERIALS AND METHODS}

\section{Fly Lines and Rearing Conditions}

Flies were reared on standard corn meal at $25^{\circ} \mathrm{C}, 60 \%$ humidity and kept in 12 hours (h) light/12 h dark (LD) conditions. 57C10-Ga14, nos-phiC31, hs-Cre on X were from the Bloomington Stock Center. vas-Cas9 was a gift from Dr. J. Ni (Tsinghua University, Beijing). UAS-Cas9 was constructed by Renbo Mao in our laboratory.

Flies used in behavioral assays were backcrossed into our isogenized Canton $\mathrm{S}$ background for 7 generations. All results of sleep analysis in this paper were obtained from female flies.

\section{Generation of KO, KI and Transgenic Lines}

Total RNA was extracted from isoCS by TRIzol reagent (Invitrogen). Using the PrimeScript II 1st Strand cDNA Synthesis Kit (Takara), we reverse-transcribed the extracted mRNA into cDNA. The UAS-Lkb1 flies was constructed by inserting the coding sequence of CG9374 amplified from cDNA into the pACU2 plasmid (a gift from the Jan Lab at UCSF) (Han et al. 2011) before being inserted into the attP40 site.

The UAS-Lkb1-sgRNA construct was designed by inserting the sgRNAs into pMt:sgRNA ${ }^{3 X E F}$ vectors based on pACU2, with rice tRNA separating the different sgRNAs. CRISPR-Gold website was used to design 3 sgRNAs of Lkb1 (Figure S3)

(Chu et al. 2016; Poe et al. 2019). The construct was inserted into the attP40 site.

$\mathrm{KO}$ and KI lines were generated as described previously (Deng et al. 2019). Knockout flies were generated with the CRISPR/Cas9 system. Two different sgRNAs 
were constructed with U6b-sgRNA plasmids. The 5' homologous arm and the 3' homologous arm of $\sim 2 \mathrm{~kb}$ amplified from the wt fly genome were inserted into a pBSK plasmid for homologous recombination repair. The cassette of attP-3P3-RFP was introduced in the middle. sgRNA plasmids and the donor plasmids were injected into vas-Cas9 embryos to introduce attP-3P3-RFP into the genome at the region of interest and replaced it by homologous recombination. 3P3-RFP served as a marker to screen for the correct flies. Primers across the homologous arms were designed to verify the sequences by PCR and DNA sequencing. attP site was introduced into the genome with 3P3-RFP-LoxP. For KI files, the nos-phiC31 virgin females were first crossed with knock-out males and the pBSK plasmid inserted with attB-T2A-Gal4-miniwhite-LoxP cassette was injected into the female embryos. Miniwhite serves as a marker to screen for the correct flies, which could be excised by the Cre/LoxP system. Primers were designed to verify the sequence by PCR and DNA sequencing.

\section{Quantitative PCR}

Total RNA was extracted from 30 flies of 5-7 days old by TRIzol reagent (Invitrogen).

The genomic template was removed using DNase (Takara). cDNA was reversetranscribed using Takara's PrimeScript II 1st Strand cDNA synthesis kit (Takara). Quantitative PCR was carried out with TransStart Top Green qPCR SuperMix kit (TransGen) in the Bio-Rad PCR system (CFX96 Touch Deep Well). The sequences of primers used to detect Lkb1 and RP49(endogenous control) mRNA are:

Lkb1-F: 5' -GCCGTCAAGATCCTGACTA-3' 
Lkb1-R: 5'-CTCCGCTGGACCAGATG-3'

Rp49-F: 5'-CGACGCTTCAAGGGACAGTATC-3'

Rp49-R: 5'-TCCGACCAGGTTACAAGAACTCTC-3'

\section{Drosophila Sleep Analysis}

Drosophila sleep analysis was performed as described previously (Dai et al. 2019; Qian et al. 2017). 5-7 days old flies were placed in a $65 \mathrm{~mm} \times 5 \mathrm{~mm}$ clear glass tube with one end containing food and the other end plugging with cotton. All flies were recorded by video-cameras. Before sleep measurement, flies were entrained to an $\mathrm{LD}$ cycle at $25^{\circ} \mathrm{C}$, $60 \%$ humidity for at least two days, and infrared LED light was used to ensure constant illumination when lights off. Immobility longer than 5 minutes was defined as one sleep event (Hendricks et al. 2000; Shaw et al. 2000). Information of fly location was tracked and sleep parameters were analyzed using Matlab (Mathworks), from which dead flies were removed. Sleep duration, sleep bout duration, sleep bout number and sleep latency for each LD were analyzed. Each experiment was repeated at least three times.

\section{Drosophila Circadian Analysis}

Flies were reared and recorded in the same condition as sleep assay as described in papers from our lab (Dai et al. 2021; Qian et al. 2017), except that the condition was constant darkness. 6-8 days activity was measured and calculated in ActogramJ (Klarsfeld et al. 2003). Rhythmic strength, power and period were calculated by Chisquare method. 


\section{Immunoblot Analysis}

Mouse brains were quickly dissected and washed with phosphate buffer saline (PBS) on ice. Lysis buffer (20mM HEPES, $10 \mathrm{mM} \mathrm{KCl}, 1.5 \mathrm{mM} \mathrm{MgCl} 2,1 \mathrm{mM}$ EDTA, $1 \mathrm{mM}$ EGTA, 1mM DTT, freshly supplemented with a protease and phosphatase inhibitors cocktail) were used to homogenize brains by homogenizer (Wiggens, D-500 pro) at $4^{\circ} \mathrm{C}$. Brain homogenates were centrifuged at 14,000 revolutions per minutes (rpm) for 15 minutes at $4^{\circ} \mathrm{C}$. The supernatant was transferred to a new microtube and quantified with bicinchoninic acid assay (Thermo Fisher, 23225). The supernatant was analyzed by SDS-PAGE and proteins were transferred to a nitrocellulose membrane (GE Healthcare, \#BA85). Membranes were incubated for $1 \mathrm{~h}$ in a blocking solution (Tris-buffered saline (TBS) containing $0.1 \%$ Tween-20, 5\% milk). Primary antibodies were anti-LKB1 (cell signaling, \#3047) and anti-actin (Santa Cruz, sc-8342).

\section{Retro-orbital Injection in Mice}

Mice were reared at controlled temperature and humidity conditions with $12 \mathrm{~h} \mathrm{light/} 12$ $\mathrm{h}$ dark cycle. Food and water were provided ad libitum. Lkb1 $1^{\mathrm{fl} / \mathrm{fl}}$ mice were from the Jackson Laboratory (JAX \#014143). They contained loxP sites flanking exons 3-6 of Lkb1 gene (Nakada et al. 2010). AAV-PHP.B-hsyn-CRE-GFP and AAV-PHP.B-hsynGFP virus were from Chinese Institute for Brain Research, Beijing. All results of sleep analysis in this paper were obtained from female mice. 
$0.2 \mathrm{ml} / 10 \mathrm{~g}$ Avertin was injected intraperitoneally into the mice for anesthetization. Rodent eyes were protruded by gentle downward pressure to the skin on the dorsal and ventral sides of the eye. The operator inserted the needle beveled downward into the retro-orbital sinus at the medial corner of the eye (Yardeni et al. 2011). The AAVPHP.B virus was injected for whole brain infection (Chan et al. 2017).

\section{Mouse Sleep Analysis}

Mouse sleep analysis was described in a previous article from our laboratory (Zhang et al. 2018). Eight-week-old mice were selected for retro-orbital injection. One week after viral injection, EEG and EMG electrode implantation procedures were performed. Mice were allowed to recover for more than 5 days individually and placed in a recording cage and tethered to an omni-directional arm (RWD Life Science Inc.) with connection cable for 2 days of habituation before recording. EEG and EMG data were recorded with custom software at a sampling frequency of $200 \mathrm{~Hz}$ for 2 consecutive days to analyze sleep/wake behavior under baseline conditions. The recording chamber was maintained at $12 \mathrm{~h} \mathrm{LD}$ cycle and controlled temperature $\left(24-25^{\circ} \mathrm{C}\right)$. EEG/EMG data were initially processed by Accusleep (Barger et al. 2019) before manual correction in SleepSign ${ }^{\mathrm{TM}}$ to improve accuracy. WAKE was scored as high amplitude and variable EMG and fast and low amplitude EEG. NREM was scored as high amplitude $\delta(1-4 \mathrm{~Hz})$ frequency EEG and low EMG tonus. REM was scored as a complete silent of EMG signals and low amplitude high frequency $\theta$ (6-9 Hz)-dominated EEG signal. 
For power spectrum analysis, EEG was subjected to fast Fourier transform (FFT) analysis with a Hamming window method by SleepSign ${ }^{\mathrm{TM}}$, yielding power spectra between $0-25 \mathrm{~Hz}$ with a $0.39 \mathrm{~Hz}$ bin resolution. Epochs containing movement artifacts were marked, included in sleep duration analysis but excluded from the power spectra analysis. Power spectra for each vigilance state represents the mean power distribution of this state during a 24-h baseline recording. The $\delta$-power density of NREMS per hour represents the average of $\delta$-power density as a percentage of $\delta$-band power $(1-4 \mathrm{~Hz})$ to total power $(0-25 \mathrm{~Hz})$ for each NREM epoch contained in an hour.

\section{Statistics}

All statistical analyses were performed with Prism 7 (GraphPad Software). Differences in means between samples larger than two groups were analyzed using ordinary Oneway ANOVA. Unpaired t test was used for two groups comparison. Power spectrum between different lines was compared by two-way ANOVA followed by Turkey's multiple comparisons test. Ns denotes $\mathrm{p}>0.05, *$ denotes $\mathrm{p}<0.05, * *$ denotes $\mathrm{p}<0.01$ and *** denotes $\mathrm{p}<0.001$ for all statistical results in this paper.

\section{SUPPLEMENTAL INFORMATION}

Supplemental information includes 5 figures.

\section{ACKNOWLEDGEMENTS}


We are grateful to Ping-ping Yan, Lan Wang and Yong-hui Zhang for fly rearing, to

Wei Yang and En-xin Zhou for Drosophila video tracing programs, to members of the

Rao lab for discussion, to the Bloomington Drosophila Stock Center for flies, to the

Jackson Laboratory for mice, to CIBR, Peking-Tsinghua Center for Life Sciences,

IDG/McGovern Institute for Brain Research at Peking University and Changping

Laboratory for support. 


\section{REFERENCES}

Alessi DR, Sakamoto K, Bayascas JR. 2006. Lkb1-dependent signaling pathways. Annu Rev Biochem. 75:137-163.

Allada R, Chung BY. 2010. Circadian organization of behavior and physiology in drosophila. Annu Rev Physiol. 72:605-624.

Allada R, Cirelli C, Sehgal A. 2017. Molecular mechanisms of sleep homeostasis in flies and mammals. Cold Spring Harb Perspect Biol. 9(8).

Anderson KA, Ribar TJ, Lin F, Noeldner PK, Green MF, Muehlbauer MJ, Witters LA, Kemp BE, Means AR. 2008. Hypothalamic camkk2 contributes to the regulation of energy balance. Cell Metab. 7(5):377-388.

Bardeesy N, Sinha M, Hezel AF, Signoretti S, Hathaway NA, Sharpless NE, Loda M, Carrasco DR, DePinho RA. 2002. Loss of the lkb1 tumour suppressor provokes intestinal polyposis but resistance to transformation. Nature. 419(6903):162167.

Barger Z, Frye CG, Liu D, Dan Y, Bouchard KE. 2019. Robust, automated sleep scoring by a compact neural network with distributional shift correction. Plos One. 14(12): 0224642 .

Beg ZH, Allmann DW, Gibson DM. 1973. Modulation of 3-hydroxy-3-methylglutaryl coenzyme a reductase activity with camp and wth protein fractions of rat liver cytosol. Biochem Biophys Res Commun. 54(4):1362-1369.

Bjorness TE, Greene RW. 2009. Adenosine and sleep. Curr Neuropharmacol. 7(3):238245.

Borbely AA. 1982. A two process model of sleep regulation. Hum Neurobiol. 1(3):195204.

Borbely AA, Baumann F, Brandeis D, Strauch I, Lehmann D. 1981. Sleep deprivation: Effect on sleep stages and eeg power density in man. Electroencephalogr Clin Neurophysiol. 51(5):483-495.

Borbely AA, Daan S, Wirz-Justice A, Deboer T. 2016. The two-process model of sleep regulation: A reappraisal. J Sleep Res. 25(2):131-143.

Brand AH, Perrimon N. 1993. Targeted gene expression as a means of altering cell fates and generating dominant phenotypes. Development. 118(2):401-415.

Carling D, Clarke PR, Zammit VA, Hardie DG. 1989. Purification and characterization of the amp-activated protein-kinase - copurification of acetyl-coa carboxylase kinase and 3-hydroxy-3-methylglutaryl-coa reductase kinase-activities. Eur J Biochem. 186(1-2):129-136.

Carling D, Zammit VA, Hardie DG. 1987. A common bicyclic protein-kinase cascade inactivates the regulatory enzymes of fatty-acid and cholesterol-biosynthesis. Febs Letters. 223(2):217-222.

Carlson CA, Kim KH. 1973. Regulation of hepatic acetyl coenzyme a carboxylase by phosphorylation and dephosphorylation. J Biol Chem. 248(1):378-380.

Carretero J, Medina PP, Pio R, Montuenga LM, Sanchez-Cespedes M. 2004. Novel and natural knockout lung cancer cell lines for the $1 \mathrm{~kb} 1 / \mathrm{stk} 11$ tumor suppressor gene. Oncogene. 23(22):4037-4040. 
Chan KY, Jang MJ, Yoo BB, Greenbaum A, Ravi N, Wu WL, Sanchez-Guardado L, Lois C, Mazmanian SK, Deverman BE et al. 2017. Engineered aavs for efficient noninvasive gene delivery to the central and peripheral nervous systems. Nat Neurosci. 20(8):1172-1179.

Chen WF, Maguire S, Sowcik M, Luo W, Koh K, Sehgal A. 2015. A neuron-glia interaction involving gaba transaminase contributes to sleep loss in sleepless mutants. Mol Psychiatry. 20(2):240-251.

Chikahisa S, Fujiki N, Kitaoka K, Shimizu N, Sei H. 2009. Central ampk contributes to sleep homeostasis in mice. Neuropharmacology. 57(4):369-374.

Choi S, Lim DS, Chung J. 2015. Feeding and fasting signals converge on the lkb1-sik3 pathway to regulate lipid metabolism in drosophila. PLoS Genet. 11(5):e1005263.

Chu VT, Graf R, Wirtz T, Weber T, Favret J, Li X, Petsch K, Tran NT, Sieweke MH, Berek $\mathrm{C}$ et al. 2016. Efficient crispr-mediated mutagenesis in primary immune cells using crisprgold and a c57bl/6 cas 9 transgenic mouse line. P Natl Acad Sci USA. 113(44):12514-12519.

Chung BY, Kilman VL, Keath JR, Pitman JL, Allada R. 2009. The gaba(a) receptor rdl acts in peptidergic pdf neurons to promote sleep in drosophila. Curr Biol. 19(5):386-390.

Cirelli C. 2009. The genetic and molecular regulation of sleep: From fruit flies to humans. Nat Rev Neurosci. 10(8):549-560.

Collet TH, van der Klaauw AA, Henning E, Keogh JM, Suddaby D, Dachi SV, Dunbar S, Kelway S, Dickson SL, Farooqi IS et al. 2016. The sleep/wake cycle is directly modulated by changes in energy balance. Sleep. 39(9):1691-1700.

Crocker A, Shahidullah M, Levitan IB, Sehgal A. 2010. Identification of a neural circuit that underlies the effects of octopamine on sleep:Wake behavior. Neuron. 65(5):670-681.

Daan S, Beersma DG, Borbely AA. 1984. Timing of human sleep: Recovery process gated by a circadian pacemaker. Am J Physiol. 246(2 Pt 2):R161-183.

Dai X, Zhou E, Yang W, Mao R, Zhang W, Rao Y. 2021. Molecular resolution of a behavioral paradox: Sleep and arousal are regulated by distinct acetylcholine receptors in different neuronal types in drosophila. Sleep. 44(7).

Dai XM, Zhow EX, Yang W, Zhang XH, Zhang WX, Rao Y. 2019. D-serine made by serine racemase in drosophila intestine plays a physiological role in sleep. Nat Commun. 10.

Davies SP, Hawley SA, Woods A, Carling D, Haystead TAJ, Hardie DG. 1994. Purification of the amp-activated protein-kinase on atp-gamma-sepharose and analysis of its subunit structure. Eur J Biochem. 223(2):351-357.

Deng B, Li Q, Liu X, Cao Y, Li B, Qian Y, Xu R, Mao R, Zhou E, Zhang W et al. 2019. Chemoconnectomics: Mapping chemical transmission in drosophila. Neuron. 101(5):876-893 e874.

Dijk DJ, Beersma DG, Daan S. 1987. Eeg power density during nap sleep: Reflection of an hourglass measuring the duration of prior wakefulness. J Biol Rhythms. 2(3):207-219. 
Donlea JM, Alam MN, Szymusiak R. 2017. Neuronal substrates of sleep homeostasis; lessons from flies, rats and mice. Curr Opin Neurobiol. 44:228-235.

Donlea JM, Pimentel D, Miesenbock G. 2014. Neuronal machinery of sleep homeostasis in drosophila. Neuron. 81(4):860-872.

Donlea JM, Thimgan MS, Suzuki Y, Gottschalk L, Shaw PJ. 2011. Inducing sleep by remote control facilitates memory consolidation in drosophila. Science. 332(6037):1571-1576.

Ferrer A, Caelles C, Massot N, Hegardt FG. 1985. Activation of rat-liver cytosolic 3hydroxy-3-methylglutaryl coenzyme a reductase kinase by adenosine 5'monophosphate. Biochem Bioph Res Co. 132(2):497-504.

Fogarty S, Hawley SA, Green KA, Saner N, Mustard KJ, Hardie DG. 2010. Calmodulin-dependent protein kinase kinase-beta activates ampk without forming a stable complex: Synergistic effects of ca2+ and amp. Biochem J. 426(1):109-118.

Foltenyi K, Greenspan RJ, Newport JW. 2007. Activation of egfr and erk by rhomboid signaling regulates the consolidation and maintenance of sleep in drosophila. Nat Neurosci. 10(9):1160-1167.

Franken P, Chollet D, Tafti M. 2001. The homeostatic regulation of sleep need is under genetic control. J Neurosci. 21(8):2610-2621.

Funato H, Miyoshi C, Fujiyama T, Kanda T, Sato M, Wang Z, Ma J, Nakane S, Tomita J, Ikkyu A et al. 2016. Forward-genetics analysis of sleep in randomly mutagenized mice. Nature. 539(7629):378-383.

Gerstner JR, Vanderheyden WM, Shaw PJ, Landry CF, Yin JCP. 2011. Fatty-acid binding proteins modulate sleep and enhance long-term memory consolidation in drosophila. Plos One. 6(1).

Gill RK, Yang SH, Meerzaman D, Mechanic LE, Bowman ED, Jeon HS, Chowdhuri SR, Shakoori A, Dracheva T, Hong KM et al. 2011. Frequent homozygous deletion of the $1 \mathrm{kb1} / \mathrm{stk} 11$ gene in non-small cell lung cancer. Oncogene. 30(35):3784-3791.

Grubbs JJ, Lopes LE, van der Linden AM, Raizen DM. 2020. A salt-induced kinase is required for the metabolic regulation of sleep. Plos Biology. 18(4).

Guldberg P, thor Straten P, Ahrenkiel V, Seremet T, Kirkin AF, Zeuthen J. 1999. Somatic mutation of the peutz-jeghers syndrome gene, $1 \mathrm{~kb} 1 / \mathrm{stk} 11$, in malignant melanoma. Oncogene. 18(9):1777-1780.

Guo F, Yi W, Zhou MM, Guo AK. 2011. Go signaling in mushroom bodies regulates sleep in drosophila. Sleep. 34(3):273-U173.

Han C, Jan LY, Jan YN. 2011. Enhancer-driven membrane markers for analysis of nonautonomous mechanisms reveal neuron-glia interactions in drosophila. Proc Natl Acad Sci U S A. 108(23):9673-9678.

Hardie DG. 2014. Amp-activated protein kinase: Maintaining energy homeostasis at the cellular and whole-body levels. Annu Rev Nutr. 34:31-55.

Hardie DG, Schaffer BE, Brunet A. 2016. Ampk: An energy-sensing pathway with multiple inputs and outputs. Trends in Cell Biology. 26(3):190-201.

Hawley SA, Boudeau J, Reid JL, Mustard KJ, Udd L, Makela TP, Alessi DR, Hardie 
DG. 2003. Complexes between the $1 \mathrm{~kb} 1$ tumor suppressor, strad alpha/beta and mo25 alpha/beta are upstream kinases in the amp-activated protein kinase cascade. J Biol. 2(4):28.

Hawley SA, Davison M, Woods A, Davies SP, Beri RK, Carling D, Hardie DG. 1996. Characterization of the amp-activated protein kinase kinase from rat liver and identification of threonine 172 as the major site at which it phosphorylates ampactivated protein kinase. Journal of Biological Chemistry. 271(44):2787927887.

Hawley SA, Pan DA, Mustard KJ, Ross L, Bain J, Edelman AM, Frenguelli BG, Hardie DG. 2005. Calmodulin-dependent protein kinase kinase-beta is an alternative upstream kinase for amp-activated protein kinase. Cell Metab. 2(1):9-19.

Hearle N, Schumacher V, Menko FH, Olschwang S, Boardman LA, Gille JJ, Keller JJ, Westerman AM, Scott RJ, Lim W et al. 2006. Frequency and spectrum of cancers in the peutz-jeghers syndrome. Clin Cancer Res. 12(10):3209-3215.

Hemminki A, Markie D, Tomlinson I, Avizienyte E, Roth S, Loukola A, Bignell G, Warren W, Aminoff M, Hoglund P et al. 1998. A serine/threonine kinase gene defective in peutz-jeghers syndrome. Nature. 391(6663):184-187.

Hemminki A, Tomlinson I, Markie D, Jarvinen H, Sistonen P, Bjorkqvist AM, Knuutila S, Salovaara R, Bodmer W, Shibata D et al. 1997. Localization of a susceptibility locus for peutz-jeghers syndrome to $19 \mathrm{p}$ using comparative genomic hybridization and targeted linkage analysis. Nat Genet. 15(1):87-90.

Hendricks JC, Finn SM, Panckeri KA, Chavkin J, Williams JA, Sehgal A, Pack AI. 2000. Rest in drosophila is a sleep-like state. Neuron. 25(1):129-138.

Herzig S, Shaw RJ. 2018. Ampk: Guardian of metabolism and mitochondrial homeostasis. Nat Rev Mol Cell Bio. 19(2):121-135.

Honda T, Fujiyama T, Miyoshi C, Ikkyu A, Hotta-Hirashima N, Kanno S, Mizuno S, Sugiyama F, Takahashi S, Funato H et al. 2018. A single phosphorylation site of sik3 regulates daily sleep amounts and sleep need in mice. Proc Natl Acad Sci U S A. 115(41):10458-10463.

Hong SP, Leiper FC, Woods A, Carling D, Carlson M. 2003. Activation of yeast snf1 and mammalian amp-activated protein kinase by upstream kinases. Proc Natl Acad Sci U S A. 100(15):8839-8843.

Hurley RL, Anderson KA, Franzone JM, Kemp BE, Means AR, Witters LA. 2005. The ca2+/calmodulin-dependent protein kinase kinases are amp-activated protein kinase kinases. J Biol Chem. 280(32):29060-29066.

Ingebritsen TS, Lee HS, Parker RA, Gibson DM. 1978. Reversible modulation of the activities of both liver microsomal hydroxymethylglutaryl coenzyme a reductase and its inactivating enzyme. Evidence for regulation by phosphorylation-dephosphorylation. Biochem Biophys Res Commun. 81(4):1268-1277.

Jan M, O'Hara BF, Franken P. 2020. Recent advances in understanding the genetics of sleep. F1000Res. 9.

Jeghers H, Mc KV, Katz KH. 1949. Generalized intestinal polyposis and melanin spots of the oral mucosa, lips and digits; a syndrome of diagnostic significance. $\mathrm{N}$ 
Engl J Med. 241(26):1031-1036.

Jenne DE, Reimann H, Nezu J, Friedel W, Loff S, Jeschke R, Muller D, Back W, Zimmer M. 1998. Peutz-jeghers syndrome is caused by mutations in a novel serine threonine kinase. Nat Genet. 18(1):38-44.

Ji HB, Ramsey MR, Hayes DN, Fan C, McNamara K, Kozlowski P, Torrice C, Wu MC, Shimamura T, Perera SA et al. 2007. Lkb1 modulates lung cancer differentiation and metastasis. Nature. 448(7155):807-U807.

Jishage K, Nezu J, Kawase Y, Iwata T, Watanabe M, Miyoshi A, Ose A, Habu K, Kake T, Kamada $\mathrm{N}$ et al. 2002. Role of lkb1, the causative gene of peutz-jegher's syndrome, in embryogenesis and polyposis. Proc Natl Acad Sci U S A. 99(13):8903-8908.

Joiner WJ, Crocker A, White BH, Sehgal A. 2006. Sleep in drosophila is regulated by adult mushroom bodies. Nature. 441(7094):757-760.

Klarsfeld A, Leloup JC, Rouyer F. 2003. Circadian rhythms of locomotor activity in drosophila. Behav Processes. 64(2):161-175.

Kunst M, Hughes ME, Raccuglia D, Felix M, Li M, Barnett G, Duah J, Nitabach MN. 2014. Calcitonin gene-related peptide neurons mediate sleep-specific circadian output in drosophila. Curr Biol. 24(22):2652-2664.

Liu QL, Liu S, Kodama L, Driscoll MR, Wu MN. 2012. Two dopaminergic neurons signal to the dorsal fan-shaped body to promote wakefulness in drosophila. Curr Biol. 22(22):2114-2123.

Liu S, Liu QL, Tabuchi M, Wu MN. 2016. Sleep drive is encoded by neural plastic changes in a dedicated circuit. Cell. 165(6):1347-1360.

Lizcano JM, Goransson O, Toth R, Deak M, Morrice NA, Boudeau J, Hawley SA, Udd L, Makela TP, Hardie DG et al. 2004. Lkb1 is a master kinase that activates 13 kinases of the ampk subfamily, including mark/par-1. Embo J. 23(4):833-843.

Lopez M, Dieguez C. 2014. Cellular energy sensors: Ampk and beyond. Mol Cell Endocrinol. 397(1-2):1-3.

Martin SG, St Johnston D. 2003. A role for drosophila lkb1 in anterior-posterior axis formation and epithelial polarity. Nature. 421(6921):379-384.

Matsumoto S, Iwakawa R, Takahashi K, Kohno T, Nakanishi Y, Matsuno Y, Suzuki K, Nakamoto M, Shimizu E, Minna JD et al. 2007. Prevalence and specificity of $1 \mathrm{~kb} 1$ genetic alterations in lung cancers. Oncogene. 26(40):5911-5918.

Mehenni H, Gehrig C, Nezu J, Oku A, Shimane M, Rossier C, Guex N, Blouin JL, Scott HS, Antonarakis SE. 1998. Loss of $1 \mathrm{kbl}$ kinase activity in peutz-jeghers syndrome, and evidence for allelic and locus heterogeneity. Am J Hum Genet. 63(6):1641-1650.

Michell BJ, Stapleton D, Mitchelhill KI, House CM, Katsis F, Witters LA, Kemp BE. 1996. Isoform-specific purification and substrate specificity of the 5'-ampactivated protein kinase. Journal of Biological Chemistry. 271(45):2844528450.

Mitchelhill KI, Stapleton D, Gao G, House C, Michell B, Katsis F, Witters LA, Kemp BE. 1994. Mammalian amp-activated protein-kinase shares structural and functional homology with the catalytic domain of yeast snf1 protein-kinase. 
Journal of Biological Chemistry. 269(4):2361-2364.

Miyoshi H, Nakau M, Ishikawa T, Seldin MF, Oshima M, Taketo MM. 2002. Gastrointestinal hamartomatous polyposis in $1 \mathrm{~kb} 1$ heterozygous knockout mice. Cancer Research. 62(8):2261-2266.

Mohawk JA, Green CB, Takahashi JS. 2012. Central and peripheral circadian clocks in mammals. Annu Rev Neurosci. 35:445-462.

Morton JP, Jamieson NB, Karim SA, Athineos D, Ridgway RA, Nixon C, Mckay CJ, Carter R, Brunton VG, Frame MC et al. 2010. Lkb1 haploinsufficiency cooperates with kras to promote pancreatic cancer through suppression of $\mathrm{p} 21$ dependent growth arrest. Gastroenterology. 139(2):586-597.

Munday MR, Carling D, Hardie DG. 1988. Negative interactions between phosphorylation of acetyl-coa carboxylase by the cyclic amp-dependent and amp-activated protein-kinases. Febs Letters. 235(1-2):144-148.

Nagy S, Maurer GW, Hentze JL, Rose M, Werge TM, Rewitz K. 2018. Ampk signaling linked to the schizophrenia-associated 1q21.1 deletion is required for neuronal and sleep maintenance. Plos Genetics. 14(12).

Nakada D, Saunders TL, Morrison SJ. 2010. Lkb1 regulates cell cycle and energy metabolism in haematopoietic stem cells. Nature. 468(7324):653-658.

Nitabach MN, Taghert PH. 2008. Organization of the drosophila circadian control circuit. Curr Biol. 18(2):R84-93.

Nixon JP, Mavanji V, Butterick TA, Billington CJ, Kotz CM, Teske JA. 2015. Sleep disorders, obesity, and aging: The role of orexin. Ageing Res Rev. 20:63-73.

Parisky KM, Agosto J, Pulver SR, Shang YH, Kuklin E, Hodge JJL, Kang K, Liu X, Garrity PA, Rosbash M et al. 2008. Pdf cells are a gaba-responsive wakepromoting component of the drosophila sleep circuit. Neuron. 60(4):672-682.

Park M, Miyoshi C, Fujiyama T, Kakizaki M, Ikkyu A, Honda T, Choi J, Asano F, Mizuno S, Takahashi S et al. 2020. Loss of the conserved pka sites of sik1 and sik2 increases sleep need. Sci Rep. 10(1):8676.

Park S, Sonn JY, Oh Y, Lim C, Choe J. 2014. Sifamide and sifamide receptor define a novel neuropeptide signaling to promote sleep in drosophila. Mol Cells. 37(4):295-301.

Peutz JLA. 1921. Very remarkable case of familial polyposis of mucous membrane of intestinal tract and nasopharynx accompanied by peculiar pigmentations of skin and mucous membrane. Nederl Maandschr Geneesk. 10:134-146.

Pimentel D, Donlea JM, Albot CBT, Ong SMS, Hurston AJFT, Miesenbock G. 2016. Operation of a homeostatic sleep switch. Nature. 536(7616):333-+.

Poe AR, Wang B, Sapar ML, Ji H, Li K, Onabajo T, Fazliyeva R, Gibbs M, Qiu Y, Hu Y et al. 2019. Robust crispr/cas9-mediated tissue-specific mutagenesis reveals gene redundancy and perdurance in drosophila. Genetics. 211(2):459-472.

Qian Y, Cao Y, Deng B, Yang G, Li J, Xu R, Zhang D, Huang J, Rao Y. 2017. Sleep homeostasis regulated by $5 \mathrm{ht} 2 \mathrm{~b}$ receptor in a small subset of neurons in the dorsal fan-shaped body of drosophila. Elife. 6 .

Rowan A, Bataille V, MacKie R, Healy E, Bicknell D, Bodmer W, Tomlinson I. 1999. Somatic mutations in the peutz-jeghers ( $1 \mathrm{kbl} /$ stkii) gene in sporadic malignant 
melanomas. J Invest Dermatol. 112(4):509-511.

Sakamoto K, McCarthy A, Smith D, Green KA, Hardie DG, Ashworth A, Alessi DR. 2005. Deficiency of $1 \mathrm{~kb} 1$ in skeletal muscle prevents ampk activation and glucose uptake during contraction. Embo J. 24(10):1810-1820.

Sanchez-Cespedes M, Parrella P, Esteller M, Nomoto S, Trink B, Engles JM, Westra $\mathrm{WH}$, Herman JG, Sidransky D. 2002. Inactivation of $1 \mathrm{~kb} 1 / \mathrm{stk} 11$ is a common event in adenocarcinomas of the lung. Cancer Research. 62(13):3659-3662.

Saper CB, Fuller PM. 2017. Wake-sleep circuitry: An overview. Current Opinion in Neurobiology. 44:186-192.

Sato F, Muragaki Y, Zhang YP. 2015. Dec1 negatively regulates ampk activity via lkb1. Biochem Bioph Res Co. 467(4):711-716.

Scammell TE, Arrigoni E, Lipton JO. 2017. Neural circuitry of wakefulness and sleep. Neuron. 93(4):747-765.

Sengupta S, Nagalingam A, Muniraj N, Bonner MY, Mistriotis P, Afthinos A, Kuppusamy P, Lanoue D, Cho S, Korangath P et al. 2017. Activation of tumor suppressor $1 \mathrm{~kb} 1$ by honokiol abrogates cancer stem-like phenotype in breast cancer via inhibition of oncogenic stat3. Oncogene. 36(41):5709-5721.

Seugnet L, Suzuki Y, Merlin G, Gottschalk L, Duntley SP, Shaw PJ. 2011. Notch signaling modulates sleep homeostasis and learning after sleep deprivation in drosophila. Curr Biol. 21(10):835-840.

Shackelford DB, Shaw RJ. 2009. The lkb1-ampk pathway: Metabolism and growth control in tumour suppression. Nat Rev Cancer. 9(8):563-575.

Shang YH, Donelson NC, Vecsey CG, Guo F, Rosbash M, Griffith LC. 2013. Short neuropeptide $\mathrm{f}$ is a sleep-promoting inhibitory modulator. Neuron. 80(1):171183.

Shang YH, Griffith LC, Rosbash M. 2008. Light-arousal and circadian photoreception circuits intersect at the large pdf cells of the drosophila brain. P Natl Acad Sci USA. 105(50):19587-19594.

Shaw PJ, Cirelli C, Greenspan RJ, Tononi G. 2000. Correlates of sleep and waking in drosophila melanogaster. Science. 287(5459):1834-1837.

Shaw RJ, Kosmatka M, Bardeesy N, Hurley RL, Witters LA, DePinho RA, Cantley LC. 2004. The tumor suppressor $1 \mathrm{~kb} 1$ kinase directly activates amp-activated kinase and regulates apoptosis in response to energy stress. P Natl Acad Sci USA. 101(10):3329-3335.

Shaw RJ, Lamia KA, Vasquez D, Koo SH, Bardeesy N, DePinho RA, Montminy M, Cantley LC. 2005. The kinase lkb1 mediates glucose homeostasis in liver and therapeutic effects of metformin. Science. 310(5754):1642-1646.

Sheeba V, Fogle KJ, Kaneko M, Rashid S, Chou YT, Sharma VK, Holmes TC. 2008. Large ventral lateral neurons modulate arousal and sleep in drosophila. Curr Biol. 18(20):1537-1545.

Shen Z, Wen XF, Lan F, Shen ZZ, Shao ZM. 2002. The tumor suppressor gene lkb1 is associated with prognosis in human breast carcinoma. Clinical Cancer Research. 8(7):2085-2090.

Skoulidis F, Byers LA, Diao LX, Papadimitrakopoulou VA, Tong P, Izzo J, Behrens C, 
Kadara H, Parra ER, Canales JR et al. 2015. Co-occurring genomic alterations define major subsets of kras-mutant lung adenocarcinoma with distinct biology, immune profiles, and therapeutic vulnerabilities. Cancer Discovery. 5(8):860877.

Sutherland CM, Hawley SA, McCartney RR, Leech A, Stark MJR, Schmidt MC, Hardie DG. 2003. Elm1p is one of three upstream kinases for the saccharomyces cerevisiae snf1 complex. Curr Biol. 13(15):1299-1305.

Taheri S, Lin L, Austin D, Young T, Mignot E. 2004. Short sleep duration is associated with reduced leptin, elevated ghrelin, and increased body mass index (bmi). Sleep. 27:146-147.

Tanwar PS, Mohapatra G, Chiang S, Engler DA, Zhang LH, Kaneko-Tarui T, Ohguchi Y, Birrer MJ, Teixeira JM. 2014. Loss of lkb1 and pten tumor suppressor genes in the ovarian surface epithelium induces papillary serous ovarian cancer. Carcinogenesis. 35(3):546-553.

Thimgan MS, Suzuki Y, Seugnet L, Gottschalk L, Shaw PJ. 2010. The perilipin homologue, lipid storage droplet 2, regulates sleep homeostasis and prevents learning impairments following sleep loss. Plos Biology. 8(8).

Tobler I, Borbely AA. 1986. Sleep eeg in the rat as a function of prior waking. Electroen Clin Neuro. 64(1):74-76.

Tomlinson IP, Houlston RS. 1997. Peutz-jeghers syndrome. J Med Genet. 34(12):10071011.

Ueno T, Tomita J, Tanimoto H, Endo K, Ito K, Kume S, Kume K. 2012. Identification of a dopamine pathway that regulates sleep and arousal in drosophila. Nat Neurosci. 15(11):1516-1523.

Wang B, Moya N, Niessen S, Hoover H, Mihaylova MM, Shaw RJ, Yates JR, 3rd, Fischer WH, Thomas JB, Montminy M. 2011. A hormone-dependent module regulating energy balance. Cell. 145(4):596-606.

Weber F, Dan Y. 2016. Circuit-based interrogation of sleep control. Nature. 538(7623):51-59.

Werth E, Dijk DJ, Achermann P, Borbely AA. 1996. Dynamics of the sleep eeg after an early evening nap: Experimental data and simulations. Am J Physiol. 271(3 Pt 2):R501-510.

Westerman AM, Entius MM, de Baar E, Boor PP, Koole R, van Velthuysen ML, Offerhaus GJ, Lindhout D, de Rooij FW, Wilson JH. 1999. Peutz-jeghers syndrome: 78-year follow-up of the original family. Lancet. 353(9160):12111215.

Wingo SN, Gallardo TD, Akbay EA, Liang MC, Contreras CM, Boren T, Shimamura T, Miller DS, Sharpless NE, Bardeesy N et al. 2009. Somatic lkb1 mutations promote cervical cancer progression. Plos One. 4(4):e5137.

Woods A, Dickerson K, Heath R, Hong SP, Momcilovic M, Johnstone SR, Carlson M, Carling D. 2005. Ca2+/calmodulin-dependent protein kinase kinase-beta acts upstream of amp-activated protein kinase in mammalian cells. Cell Metab. 2(1):21-33

Woods A, Johnstone SR, Dickerson K, Leiper FC, Fryer LG, Neumann D, Schlattner 
U, Wallimann T, Carlson M, Carling D. 2003. Lkb1 is the upstream kinase in the amp-activated protein kinase cascade. Curr Biol. 13(22):2004-2008.

Yardeni T, Eckhaus M, Morris HD, Huizing M, Hoogstraten-Miller S. 2011. Retroorbital injections in mice. Lab Animal. 40(5):155-160.

Yeh LA, Kim KH. 1980. Regulation of acetyl-coa carboxylase - properties of coa activation of acetyl-coa carboxylase. P Natl Acad Sci-Biol. 77(6):3351-3355.

Yi W, Zhang YP, Tian YJ, Guo J, Li Y, Guo AK. 2013. A subset of cholinergic mushroom body neurons requires go signaling to regulate sleep in drosophila. Sleep. 36(12):1809-1821.

Yurgel ME, Kakad P, Zandawala M, Nassel DR, Godenschwege TA, Keene AC. 2019. A single pair of leucokinin neurons are modulated by feeding state and regulate sleep-metabolism interactions. Plos Biology. 17(2).

Zhang X, Yan H, Luo Y, Huang Z, Rao Y. 2018. Thermoregulation-independent regulation of sleep by serotonin revealed in mice defective in serotonin synthesis. Mol Pharmacol. 93(6):657-664. 


\section{FIGURE LEGENDS}

\section{Figure 1. Sleep Phenotypes of Lkb1 Knock-Down Mutants.}

(A) A diagram illustrating the Lkb1 insertion mutant $1 \mathrm{~kb} 1^{\mathrm{T} 2}$.

(B) Relative Lkb1 mRNA levels in $1 \mathrm{~kb} 1^{\mathrm{T} 2 / \mathrm{T} 2}$ (red), $1 \mathrm{~kb} 1^{\mathrm{T} 2 /+}$ (blue) and wt (black) flies.

(C) Sleep profiles of $1 \mathrm{~kb} 1^{\mathrm{T} 2 / \mathrm{T} 2}$ (red, $\mathrm{n}=42$ ), $1 \mathrm{~kb} 1^{\mathrm{T} 2 /+}$ (blue, $\mathrm{n}=44$ ), and wt (black, $\mathrm{n}=44$ ) flies in a $12 \mathrm{~h}$ light/12 h dark (LD) cycle.

(D-G) Statistical analysis of sleep duration, sleep bout number, sleep bout duration and latency to sleep in $1 \mathrm{~kb} 1^{\mathrm{T} 2 / \mathrm{T} 2}$ (red, $\left.\mathrm{n}=42\right), \mathrm{kb}^{\mathrm{T} 2 /+}$ (blue, $\mathrm{n}=44$ ) and wt (black, $\mathrm{n}=44$ ) flies. Open bars denote daytime, filled bars denote nighttime.

(D) Sleep duration. Daytime and nighttime sleep durations of $1 \mathrm{~kb} 1^{\mathrm{T} 2 / \mathrm{T} 2}$ mutants was significantly less than those in $1 \mathrm{~kb} 1^{\mathrm{T} 2 /+}$ and wt flies.

(E) Sleep bout number. Daytime sleep bout number of $1 \mathrm{~kb} 1^{\mathrm{T} 2 / \mathrm{T} 2}$ mutants was less than that of $1 \mathrm{kbl}^{\mathrm{T} 2 /+}$ flies. Nighttime sleep bout number of $1 \mathrm{~kb} 1^{\mathrm{T} 2 / \mathrm{T} 2}$ was significantly less than those of $1 \mathrm{~kb} 1^{\mathrm{T} 2 /+}$ and wt flies.

(F) Sleep bout duration. Nighttime sleep bout duration of $1 \mathrm{~kb} 1^{\mathrm{T} 2 / \mathrm{T} 2}$ mutants was significantly less than those of $1 \mathrm{~kb} 1^{\mathrm{T} 2 /+}$ and wt flies.

(G) Latency to sleep. Latency to sleep after light-off of $1 \mathrm{~kb} 1^{\mathrm{T} 2 / \mathrm{T} 2}$ mutants was significantly prolonged than $1 \mathrm{~kb} 1^{\mathrm{T} 2 /+}$ and wt flies.

Ordinary One-way ANOVA was used. n.s. denotes $\mathrm{p}>0.05,{ }^{*} \mathrm{p}<0.05,{ }^{*} \mathrm{p}<0.01$, $* * * p<0.001$. Error bars represent standard error of the mean (SEM).

Figure 2. Rescue of Sleep Loss in $1 \mathrm{kb1} 1^{\mathrm{T} 2 / \mathrm{T} 2}$ by Lkb1. 
(A) A diagram of $1 \mathrm{~kb} 1^{\mathrm{T} 2}$-Gal4: a cDNA for the yeast Gal4 gene inserted in the $1 \mathrm{kb1}{ }^{\mathrm{T} 2}$ knockdown mutants.

(B) Relative Lkb1 mRNA levels in $1 \mathrm{~kb}^{\mathrm{T} 2 / \mathrm{T} 2}-\mathrm{Gal} 4$ (blue), UAS-Lkb1; $1 \mathrm{~kb} 1^{\mathrm{T} 2 / \mathrm{T} 2}$ Gal4 (red), UAS-Lkb1; lkb1 $1^{\mathrm{T} 2 / \mathrm{T} 2}$ (yellow) and wt (black) flies.

(C-G) In $1 \mathrm{~kb} 1^{\mathrm{T} 2 / \mathrm{T} 2}$-Gal4 homozygous flies, UAS-Lkb1 cDNA driven by Gal4 to rescue sleep phenotypes of lkb1 knockdown mutants.

(C) Sleep profiles of UAS-Lkb1; $1 \mathrm{~kb}^{\mathrm{T} 2 / \mathrm{T} 2}-\mathrm{Gal} 4$ (red, $\left.\mathrm{n}=45\right)$, UAS-Lkb1; $1 \mathrm{~kb} 1^{\mathrm{T} 2 / \mathrm{T} 2}$ (yellow, $\mathrm{n}=47$ ), $1 \mathrm{~kb} 1^{\mathrm{T} 2 / \mathrm{T} 2}$-Gal4 (blue, $\mathrm{n}=46$ ) and wt (black, $\mathrm{n}=36$ ) flies.

(D-G) Statistical analysis of sleep duration, sleep bout number, sleep bout duration and latency to sleep in UAS-Lkb1; $1 \mathrm{~kb} 1^{\mathrm{T} 2 / \mathrm{T} 2}-\mathrm{Gal} 4$ (red, $\left.\mathrm{n}=45\right)$, UAS-Lkb1; $1 \mathrm{kb1} 1^{\mathrm{T} 2 / \mathrm{T} 2}$ (yellow, $\mathrm{n}=47$ ), lkb1 $1^{\mathrm{T} 2 / \mathrm{T} 2}-$ Gal4 (blue, $\mathrm{n}=46$ ) and wt (black, $\mathrm{n}=36$ ) flies. Open bars denote daytime, filled bars nighttime.

(D) Sleep duration. Nighttime sleep duration of UAS-Lkb1; $1 k b 1^{\mathrm{T} 2 / \mathrm{T} 2}-\mathrm{Gal} 4$ was similar to that of wt mutants, both significantly higher than UAS-Lkb1; lkb1 $1^{\mathrm{T} 2 / \mathrm{T} 2}$ and $1 \mathrm{~kb} 1^{\mathrm{T} 2 / \mathrm{T} 2}-\mathrm{Gal} 4$ flies.

(E) Sleep bout number. Nighttime sleep bout number of UAS-Lkb1; 1kb1 ${ }^{\mathrm{T} 2 / \mathrm{T} 2}$-Gal4 was similar to the wt but significantly higher than UAS-Lkb1; $1 \mathrm{~kb} 1^{\mathrm{T} 2 / \mathrm{T} 2}$ and $1 \mathrm{~kb} 1^{\mathrm{T} 2 / \mathrm{T} 2}-\mathrm{Gal} 4$ flies.

(F) Sleep bout duration. Nighttime sleep bout duration of UAS-Lkb1; lkb1 $1^{\mathrm{T} 2 / \mathrm{T} 2}$ Gal4 was similar to the wt but significantly higher than UAS-Lkb1; $1 \mathrm{~kb} 1^{\mathrm{T} 2 / \mathrm{T} 2}$ and lkb1 ${ }^{\mathrm{T} 2 / \mathrm{T} 2}-\mathrm{Gal} 4$ flies. 
(G) Latency to sleep. Latency after light-off of UAS-Lkb1; $1 \mathrm{~kb} 1^{\mathrm{T} 2 / \mathrm{T} 2}-\mathrm{Gal} 4$ was similar to the wt but significantly shorter than UAS-Lkb1; $1 \mathrm{~kb} 1^{\mathrm{T} 2 / \mathrm{T} 2}$ and $1 \mathrm{~kb} 1^{\mathrm{T} 2 / \mathrm{T} 2}$ Gal4 flies.

Unpaired t test was used. n.s. denotes $\mathrm{p}>0.05, * \mathrm{p}<0.05, * * \mathrm{p}<0.01, * * * \mathrm{p}<0.001$. Error bars represent SEM.

Figure 3. Sleep Phenotypes of Mutants from Whose Neurons Lkb1 Was Targeted.

(A) Sleep profiles of UAS-Lkb1-sgRNA/57C10-Gal4;+/UAS-Cas9 (red, n=22), UASLkb1-sgRNA/57C10-Ga14 (blue, n=24), and 57C10-Gal4/+;+/UAS-Cas9 (black, n=24) flies.

(B-E) Statistical analysis of sleep duration, sleep bout number, sleep bout duration and latency to sleep in UAS-Lkb1-sgRNA/57C10-Gal4;+/UAS-Cas9 (red, n=22), UASLkb1-sgRNA/57C10-Gal4 (blue, n=24) and 57C10-Gal4/+;+/UAS-Cas9 (black, n=24) flies. Open bars denote daytime, filled bars nighttime.

(B) Sleep duration. Nighttime sleep duration of UAS-Lkb1-sgRNA/57C10Gal4;+/UAS-Cas9 was significantly less than those of UAS-Lkb1-sgRNA/57C10Gal4 and 57C10-Gal4/+;+/UAS-Cas9 flies.

(C) Sleep bout number. Daytime and nighttime sleep bout numbers of UAS-Lkb1sgRNA/57C10-Gal4;+/UAS-Cas9 was not significantly from those of UAS-Lkb1sgRNA/57C10-Gal4 and 57C10-Gal4/+,+/UAS-Cas9 flies. 
(D) Sleep bout duration. Nighttime sleep bout duration of UAS-Lkb1sgRNA/57C10-Gal4;+/UAS-Cas9 was significantly less than that of UAS-Lkb1sgRNA/57C10-Gal4 and 57C10-Gal4/+,+/UAS-Cas9 flies.

(E) Latency to sleep. Latency to sleep after light-off of UAS-Lkb1-sgRNA/57C10Gal4;+/UAS-Cas9 was longer than that of 57C10-Gal4/+;+/UAS-Cas9 which was not significantly different from that of UAS-Lkb1-sgRNA/57C10-Gal4 flies.

Ordinary One-way ANOVA was used. n.s. denotes $\mathrm{p}>0.05,{ }^{*} \mathrm{p}<0.05,{ }^{* *} \mathrm{p}<0.01$, $* * * \mathrm{p}<0.001$. Error bars represent SEM.

Figure 4. Sleep Phenotypes of LKB1 Conditional Knockout Mice.

(A) Levels of LKB1 protein from Lkb1 ${ }^{\mathrm{fl} / \mathrm{fl}}$ mice injected with AAV-hsyn-Cre-GFP virus $\left(\mathrm{Cre}^{+} \mathrm{Lkb}^{\mathrm{fl} / \mathrm{fl}}, \mathrm{n}=4\right), \mathrm{Lkb} 1^{\mathrm{fl} / \mathrm{fl}}$ mice injected with AAV-hsyn-GFP virus $\left(\mathrm{GFP}^{+} \mathrm{Lkb}^{\mathrm{fl} / \mathrm{fl}}\right.$, $\mathrm{n}=3), \mathrm{Lkb1}^{\mathrm{fl} /+}$ mice injected with AAV-hsyn-Cre-GFP virus $\left(\mathrm{Cre}^{+} \mathrm{Lkb1}^{\mathrm{fl} /+}, \mathrm{n}=2\right)$ and $\mathrm{Lkbl}^{+/+}$mice injected with AAV-hsyn-Cre-GFP virus $\left(\mathrm{Cre}^{+} \mathrm{Lkb}^{+/+}, \mathrm{n}=2\right)$. These mice were among those used for EEG recording and analysis.

(B) Levels of LKB1 protein in individual mice (genotypes labelled: $\mathrm{Cre}^{+} \mathrm{Lkb1}^{\mathrm{fl} / \mathrm{fl}}, \mathrm{GFP}^{+}$ $\mathrm{Lkb1}^{\mathrm{fl} / \mathrm{fl}}, \mathrm{Cre}^{+} \mathrm{Lkb1}^{\mathrm{fl} / /}$ and $\mathrm{Cre}^{+} \mathrm{Lkb1}^{+/+}$. These mice were the same mice as those in (A) but presented individually.

(C, E, G) Statistical analysis of wake duration, NREM duration and REM duration in $\mathrm{Cre}^{+} \mathrm{Lkb1}^{\mathrm{fl} / \mathrm{fl}}$ (red, $\left.\mathrm{n}=10\right), \mathrm{GFP}^{+} \mathrm{Lkbl}^{\mathrm{fl} / \mathrm{fl}}$ (yellow, $\left.\mathrm{n}=5\right), \mathrm{Cre}^{+} \mathrm{Lkb1}^{\mathrm{fl} /+}(\mathrm{blue}, \mathrm{n}=7$ ) and $\mathrm{Cre}^{+} \mathrm{Lkb1}^{+/+}$(black, $\mathrm{n}=4$ ) mice in a 12:12 LD cycle. White background denotes daytime, gray background nighttime. 
(C) Wake duration. Daytime wake duration of $\mathrm{Cre}^{+} \mathrm{Lkb1}^{\mathrm{fl} / \mathrm{fl}}$ mice was higher than those of $\mathrm{GFP}^{+} \mathrm{Lkb1}^{\mathrm{fl} / \mathrm{fl}}, \mathrm{Cre}^{+} \mathrm{Lkb1}^{\mathrm{fl} /+}$ or $\mathrm{Cre}^{+} \mathrm{Lkb1}^{+/+}$mice. Nighttime wake duration of $\mathrm{Cre}^{+} \mathrm{Lkb}^{\mathrm{fl} / \mathrm{fl}}$ mice was higher than that of $\mathrm{GFP}^{+} \mathrm{Lkb} 1^{\mathrm{fl} / \mathrm{fl}}$ mice.

(E) NREM duration. Daytime NREM duration of $\mathrm{Cre}^{+} \mathrm{Lkb} 1^{\mathrm{fl} / \mathrm{fl}}$ mice was lower than those of $\mathrm{GFP}^{+} \mathrm{Lkbl}^{\mathrm{fl} / \mathrm{fl}}, \mathrm{Cre}^{+} \mathrm{Lkb1}^{\mathrm{fl} /+}$ and $\mathrm{Cre}^{+} \mathrm{Lkb1}^{+/+}$mice. Nighttime NREM duration of $\mathrm{Cre}^{+} \mathrm{Lkb}^{\mathrm{fl} / \mathrm{fl}}$ mice was lower than that of $\mathrm{GFP}^{+} \mathrm{Lkb} 1^{\mathrm{fl} / \mathrm{fl}}$ mice.

(G) REM duration. Daytime and nighttime REM durations of $\mathrm{Cre}^{+} \mathrm{Lkb}^{\mathrm{fl} / \mathrm{fl}}$ mice was not significantly different from those of $\mathrm{GFP}^{+} \mathrm{Lkb}^{\mathrm{fl} / \mathrm{fl}}, \mathrm{Cre}^{+} \mathrm{Lkb}^{\mathrm{fl} /+}$ and $\mathrm{Cre}^{+}$ $\mathrm{Lkb}^{+/+}$mice.

(D, F, H) EEG power spectrum of (D) WAKE, (F) NREM and (H) REM states in $\mathrm{Cre}^{+} \mathrm{Lkb}^{\mathrm{fl} / \mathrm{fl}}(\mathrm{red}, \mathrm{n}=8), \mathrm{GFP}^{+} \mathrm{Lkb1}^{\mathrm{fl} / \mathrm{fl}}$ (yellow, $\left.\mathrm{n}=5\right), \mathrm{Cre}^{+} \mathrm{Lkb1}^{\mathrm{fl} /+}($ blue, $\mathrm{n}=6)$ and $\mathrm{Cre}^{+} \mathrm{Lkb1}^{+/+}$(black, $\left.\mathrm{n}=4\right)$ mice.

(I) NREM $\delta$-power density of $\mathrm{Cre}^{+} \mathrm{Lkb}^{\mathrm{fl} / \mathrm{fl}}(\mathrm{red}, \mathrm{n}=8), \mathrm{GFP}^{+} \mathrm{Lkb}^{\mathrm{fl} / \mathrm{fl}}$ (yellow, $\mathrm{n}=5$ ), $\mathrm{Cre}^{+} \mathrm{Lkb}^{\mathrm{fl} /+}$ (blue, $\left.\mathrm{n}=6\right)$ and $\mathrm{Cre}^{+} \mathrm{Lkb1}^{+/+}$(black, $\left.\mathrm{n}=4\right)$ mice.

Ordinary One-way ANOVA was used in C, E, G for comparison of $\mathrm{Cre}^{+} \mathrm{Lkb}^{\mathrm{fl} / \mathrm{fl}}$, $\mathrm{Cre}^{+} \mathrm{Lkbl}^{\mathrm{fl} /+}$ and $\mathrm{Cre}^{+} \mathrm{Lkbl}^{+/+}$mice. Unpaired t test was used in $\mathrm{C}, \mathrm{E}, \mathrm{G}$ for comparison of $\mathrm{Cre}^{+} \mathrm{Lkb}^{\mathrm{fl} / \mathrm{fl}}$ and $\mathrm{GFP}^{+} \mathrm{Lkb1}^{\mathrm{fl} / \mathrm{fl}}$ mice. Two-way ANOVA followed by Turkey's multiple comparisons test was used in D, F, H, I. n.s. denotes p $>0.05$, ${ }^{*} \mathrm{p}<0.05, * * \mathrm{p}<0.01, * * * \mathrm{p}<0.001$. Error bars represent SEM.

\section{Legends for Supplemental Figures}




\section{Figure S1. Sleep Profiles of Lkb1 Knockout Mutants.}

(A) A diagram representation of Lkb1 knock-out mutants $1 \mathrm{~kb} 1^{\mathrm{T} 1}$.

(B) Relative Lkb1 mRNA levels in $1 \mathrm{~kb} 1^{\mathrm{T} 1 /+}$ (blue) and wt (black) flies. $1 \mathrm{~kb} 1^{\mathrm{T} 1 / \mathrm{T} 1}$

was lethal.

(C) Sleep profiles of $1 \mathrm{~kb}^{\mathrm{T} 1 /+}$ (blue, $\mathrm{n}=71$ ) and wt (black, $\mathrm{n}=84$ ) flies.

(D-G) Statistical analysis of sleep duration, sleep bout number, sleep bout duration and latency to sleep in $1 \mathrm{~kb} 1^{\mathrm{T} 1 /+}$ (blue, $\mathrm{n}=71$ ) and wt (black, $\mathrm{n}=84$ ) flies. Open bars denote daytime, filled bars nighttime.

(D) Sleep duration. Nighttime sleep duration of $1 \mathrm{~kb} 1^{\mathrm{Tl} /+}$ was lower than that of wt flies.

(E) Sleep bout number. Daytime and nighttime sleep bout numbers of $1 \mathrm{~kb} 1^{\mathrm{T} 1 /+}$ were not significantly from those of wt flies.

(F) Sleep bout duration. Nighttime sleep bout duration of $1 \mathrm{~kb} 1^{\mathrm{T} 1 /+}$ was lower than that of wt flies.

(G) Latency to sleep. Latency to sleep after light-off of $1 \mathrm{~kb} 1^{\mathrm{T} 1 /+}$ was longer than that of wt flies.

Unpaired $\mathrm{t}$ test was used. n.s. denotes $\mathrm{p}>0.05,{ }^{*} \mathrm{p}<0.05, * * \mathrm{p}<0.01, * * * \mathrm{p}<0.001$. Error bars represent SEM

Figure S2. Genotype Confirmation for $l k b 1^{\mathrm{T} 2}$.

(A) A diagram of $1 \mathrm{~kb} 1^{\mathrm{T} 2}$ and the PCR primers used to detect inserted sequences.

(B) Polymerase chain reaction (PCR) confirmation of the inserted sequences. 


\section{Figure S3. Lkb1-sgRNA}

A diagram of Lkb1 sgRNA. Three sgRNA were designed.

\section{Figure S4. Sleep Profiles of Lkb1-CKO in Mice.}

(A) Time spent in wake of $\mathrm{Cre}^{+} \mathrm{Lkb}^{\mathrm{fl} / \mathrm{fl}}(\mathrm{red}, \mathrm{n}=10), \mathrm{GFP}^{+} \mathrm{Lkb}^{\mathrm{fl} / \mathrm{fl}}$ (yellow, $\left.\mathrm{n}=5\right), \mathrm{Cre}^{+}$ $\mathrm{Lkb1}^{\mathrm{fl} /+}$ (blue, $\left.\mathrm{n}=7\right)$ and $\mathrm{Cre}^{+} \mathrm{Lkb}^{+/+}$(black, $\left.\mathrm{n}=4\right)$ mice in a $12 \mathrm{~h}$ light/12 $\mathrm{h}$ dark (LD) cycle.

(B) Time spent in NREM of $\mathrm{Cre}^{+} \mathrm{Lkb1}^{\mathrm{fl} / \mathrm{fl}}(\mathrm{red}, \mathrm{n}=10), \mathrm{GFP}^{+} \mathrm{Lkb}^{\mathrm{fl} / \mathrm{fl}}$ (yellow, $\left.\mathrm{n}=5\right)$, $\mathrm{Cre}^{+} \mathrm{Lkb1}^{\mathrm{fl} /+}$ (blue, $\mathrm{n}=7$ ) and $\mathrm{Cre}^{+} \mathrm{Lkb1}^{+/+}$(black, $\left.\mathrm{n}=4\right)$ mice in an LD cycle.

(C) Time spent in REM of $\mathrm{Cre}^{+} \mathrm{Lkb}^{\mathrm{fl} / \mathrm{fl}}$ (red, $\left.\mathrm{n}=10\right), \mathrm{GFP}^{+} \mathrm{Lkb}^{\mathrm{fl} / \mathrm{fl}}$ (yellow, $\mathrm{n}=5$ ), $\mathrm{Cre}^{+}$ $\mathrm{Lkb1}^{\mathrm{fl} / /}$ (blue, $\mathrm{n}=7$ ) and $\mathrm{Cre}^{+} \mathrm{Lkb}^{+/+}$(black, $\left.\mathrm{n}=4\right)$ mice in an LD cycle.

\section{Figure S5. Circadian Rhythm in Lkb1 Mutant Flies}

(A) Relative rhythmic power in wt (black, $\mathrm{n}=42,4 / 42$ arrhythmic), $1 \mathrm{~kb} 1^{\mathrm{T} 2 /+}$ (blue, $\mathrm{n}=44,0 / 44$ arrhythmic) and $1 \mathrm{~kb} 1^{\mathrm{T} 2 / \mathrm{T} 2}(\mathrm{red}, \mathrm{n}=37,0 / 37$ arrhythmic) flies. The Power of $1 \mathrm{~kb} 1^{\mathrm{T} 2 /+}$ and $1 \mathrm{~kb} 1^{\mathrm{T} 2 / \mathrm{T} 2}$ were significantly higher than wt flies.

(B) Period length in wt (black, $\mathrm{n}=42$ ), $1 \mathrm{~kb} 1^{\mathrm{T} 2 /+}$ (blue, $\mathrm{n}=44$ ) and $1 \mathrm{~kb} 1^{\mathrm{T} 2 / \mathrm{T} 2}$ (red, $\mathrm{n}=37$ )

flies. The period of $1 \mathrm{~kb} 1^{\mathrm{T} 2 / \mathrm{T} 2}$ was not significantly different from those of wt and $1 \mathrm{~kb} 1^{\mathrm{T} 2 /+}$ flies. 
(C-E) Double-plotted actograms showing locomotor activity in wt ( $\mathrm{n}=42), 1 \mathrm{~kb} 1^{\mathrm{T} 2 /+}$

$(\mathrm{n}=44)$ and $\mathrm{lkb} 1^{\mathrm{T} 2 / \mathrm{T} 2}(\mathrm{n}=37)$ flies switching from $12 \mathrm{hr}$ LD to constant darkness. Open

bars denote daytime, filled bars denote nighttime and grey background denotes DD.

Ordinary One-way ANOVA was used. n.s. denotes $\mathrm{p}>0.05,{ }^{*} \mathrm{p}<0.05, * * \mathrm{p}<0.01$, $* * * \mathrm{p}<0.001$. Error bars represent SEM. 
Figure1

A

lkb1 $1^{\mathrm{T} 2}$ Genome
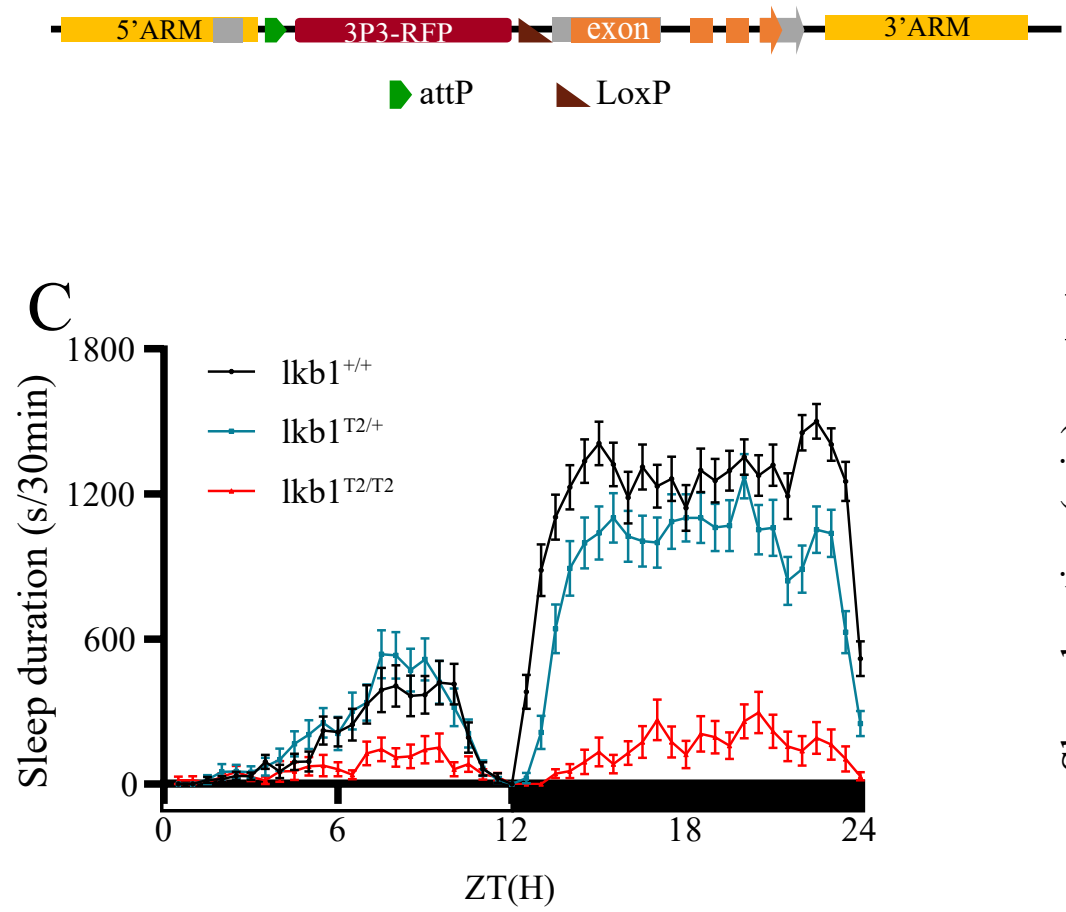

E

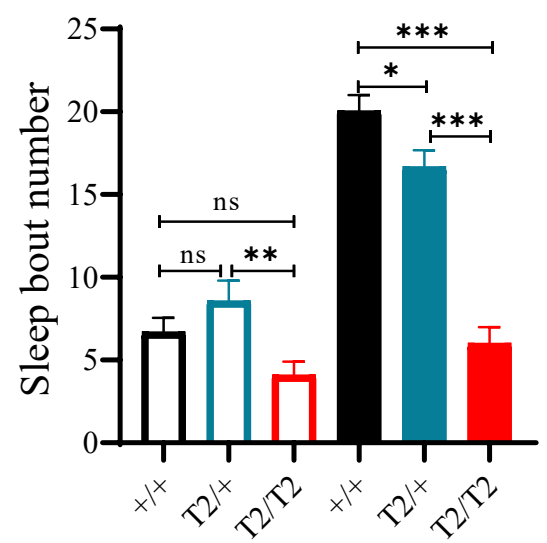

F

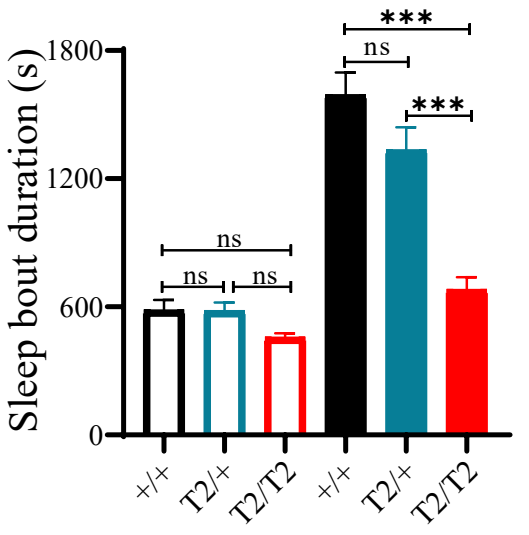

B

D
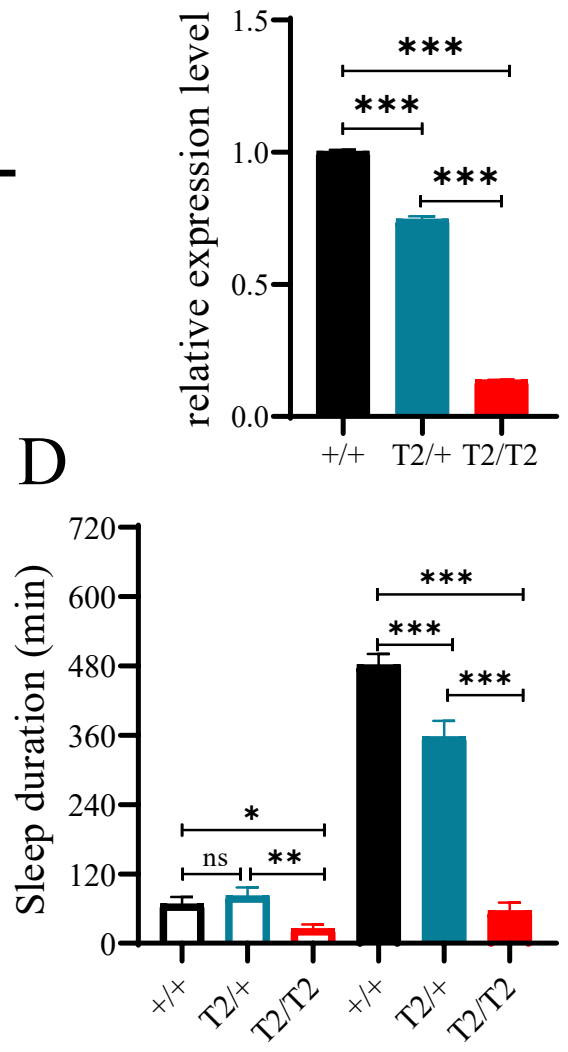

G

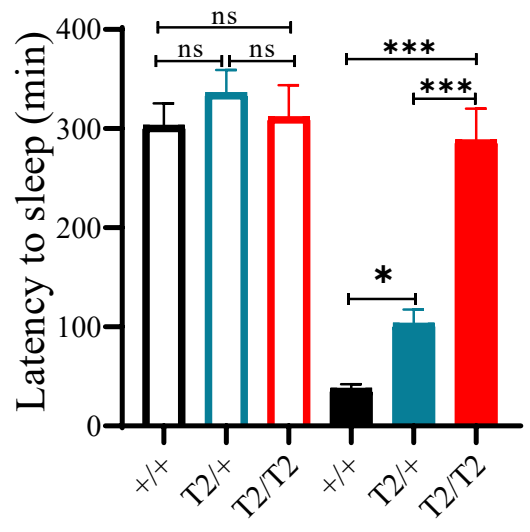




\section{A}

lkb1 ${ }^{\mathrm{T} 2}$ Genome

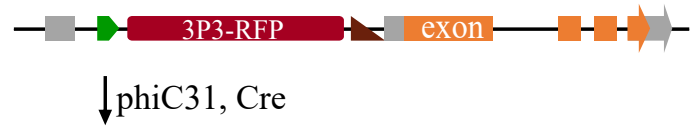

lkb1 $1^{\mathrm{T} 2}$-Gal4 Genome

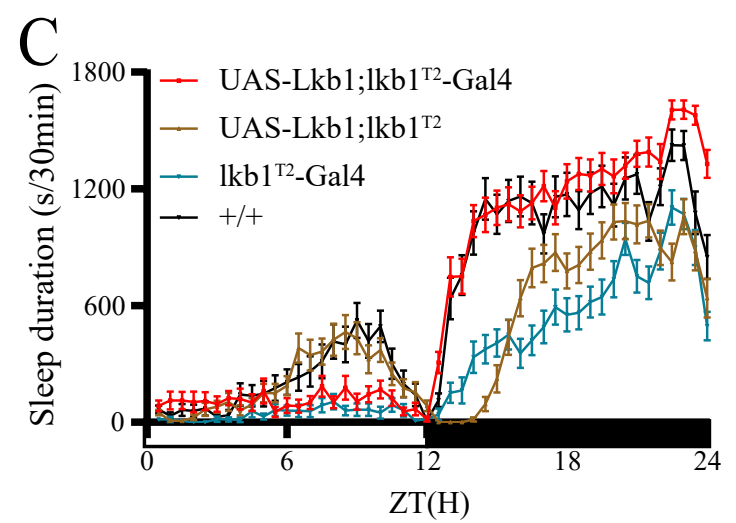

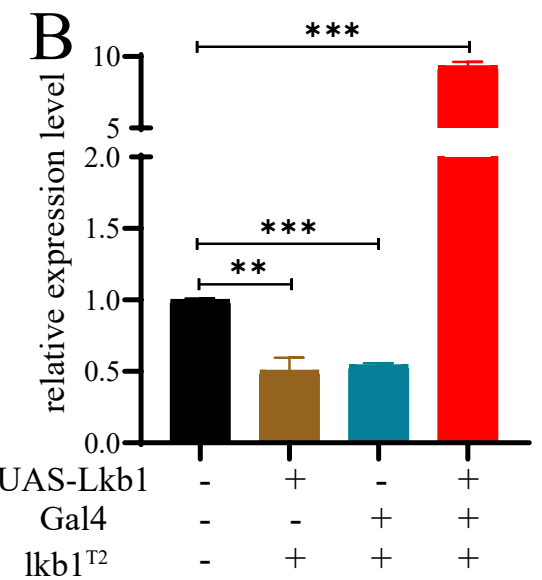

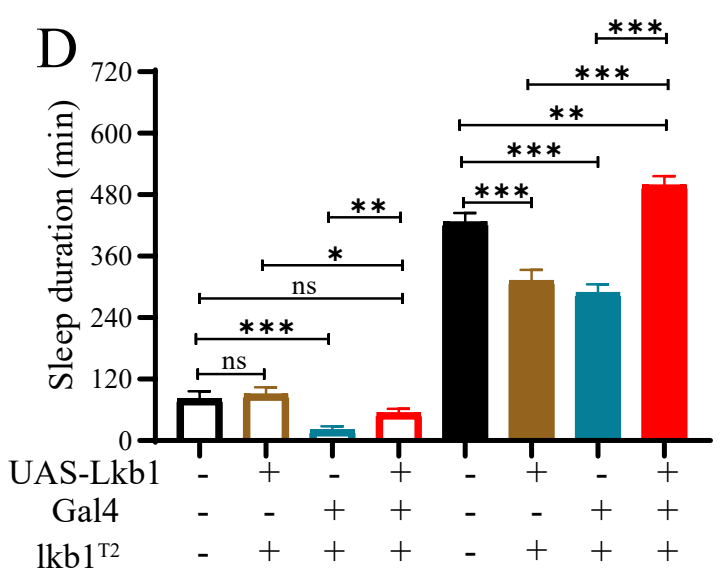

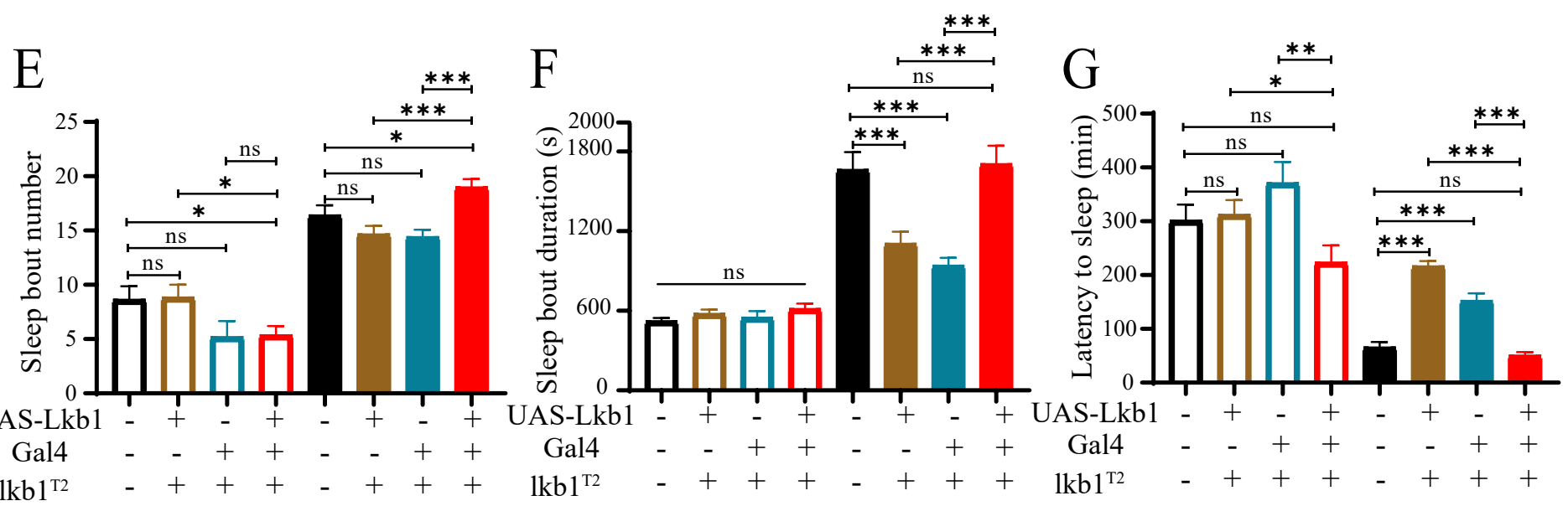




\section{Figure3}
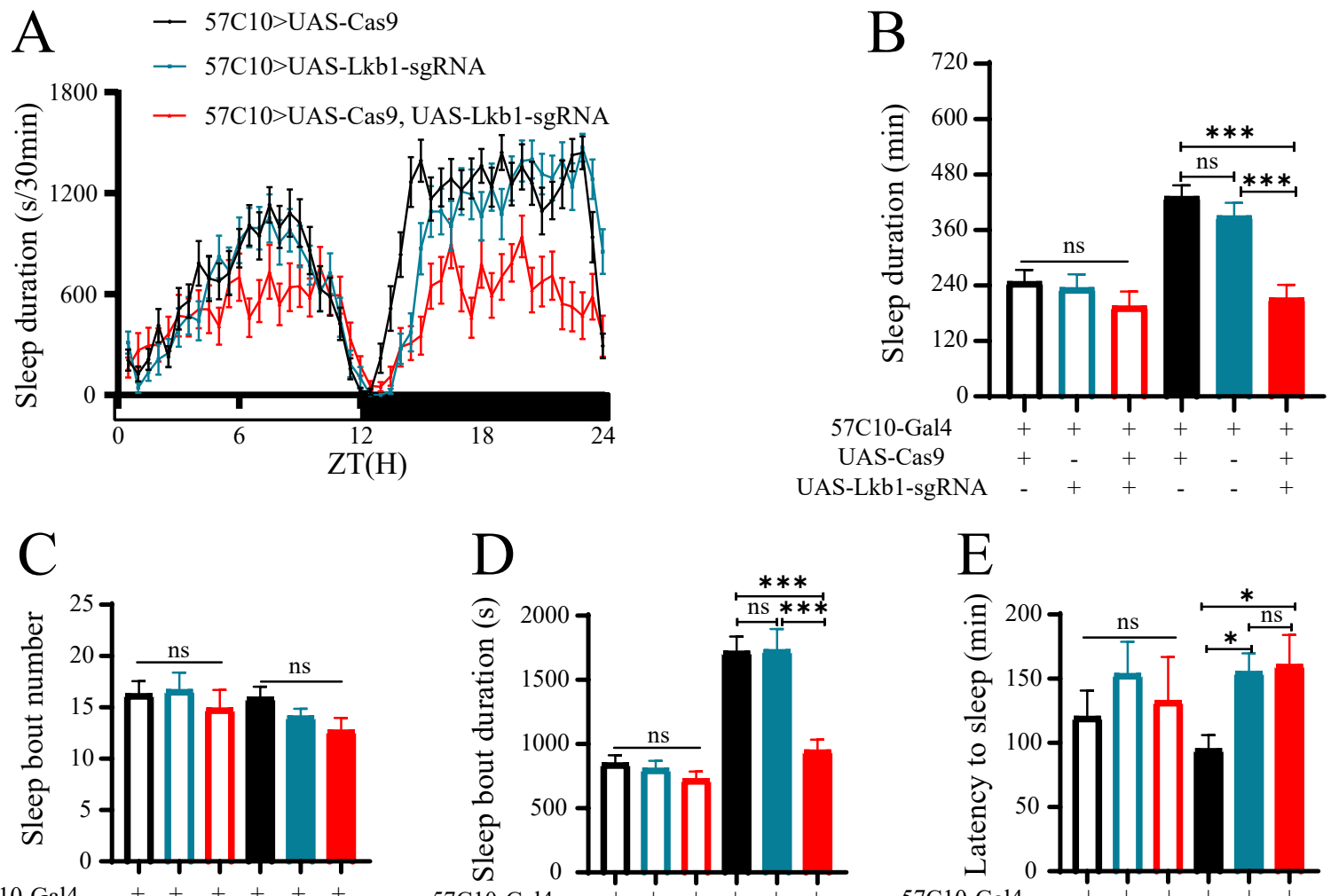

57C10-Gal4

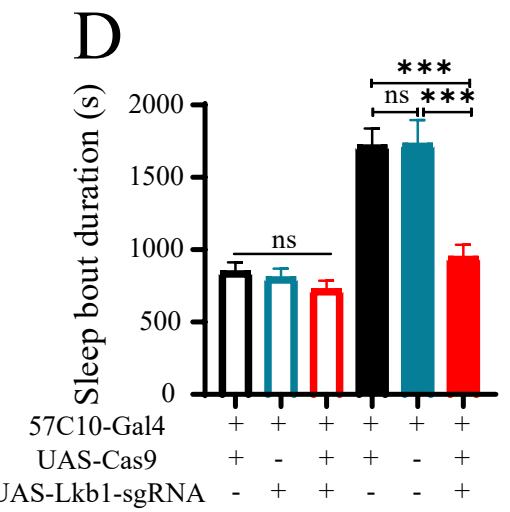

UAS-Cas9

UAS-Lkb1-sgRNA

E

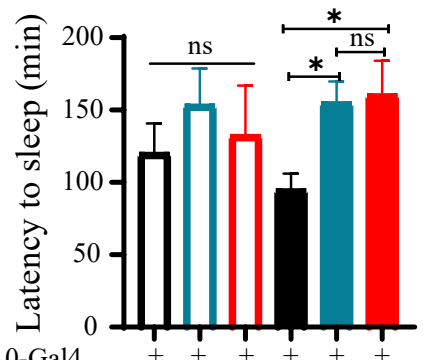

57C10-Gal4

UAS-Cas9

UAS-Lkb1-sgRNA 
A

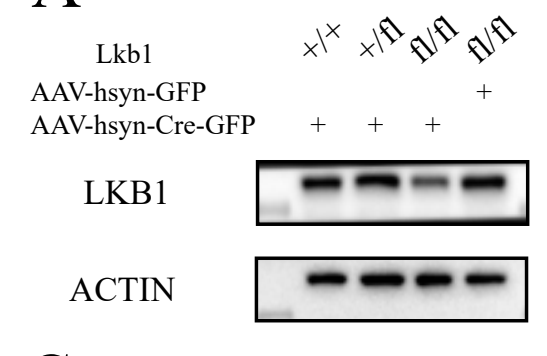

C

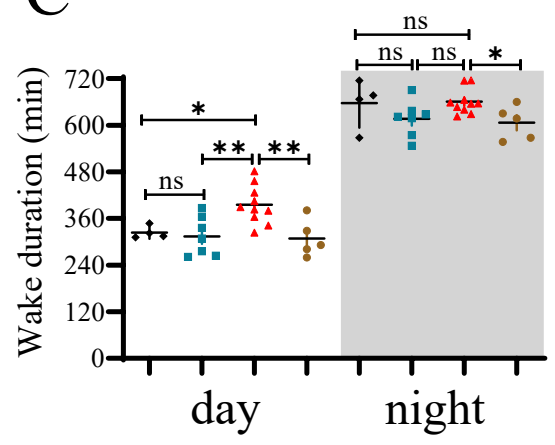

$\mathrm{E}$

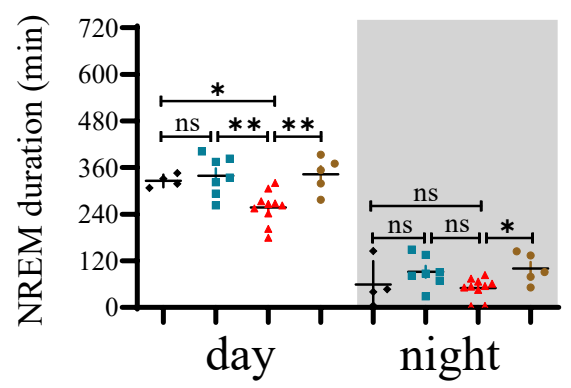

G

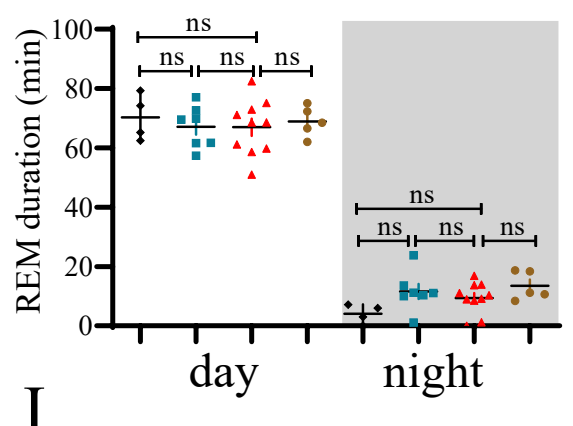

B

Lkb1

AAV-hsyn-GFP

AAV-hsyn-Cre-GFP

LKB1

ACTIN

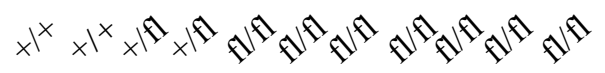


A

Lkb1 Genome vector

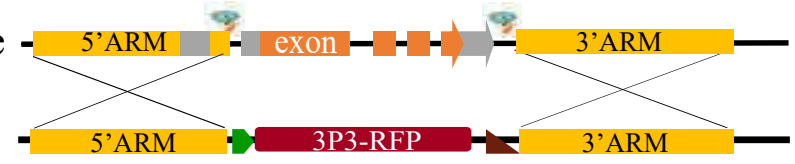

!HR

lkb1 ${ }^{\mathrm{T} 1}$ Genome

\% Cas9/sgRNA attP LoxP

C

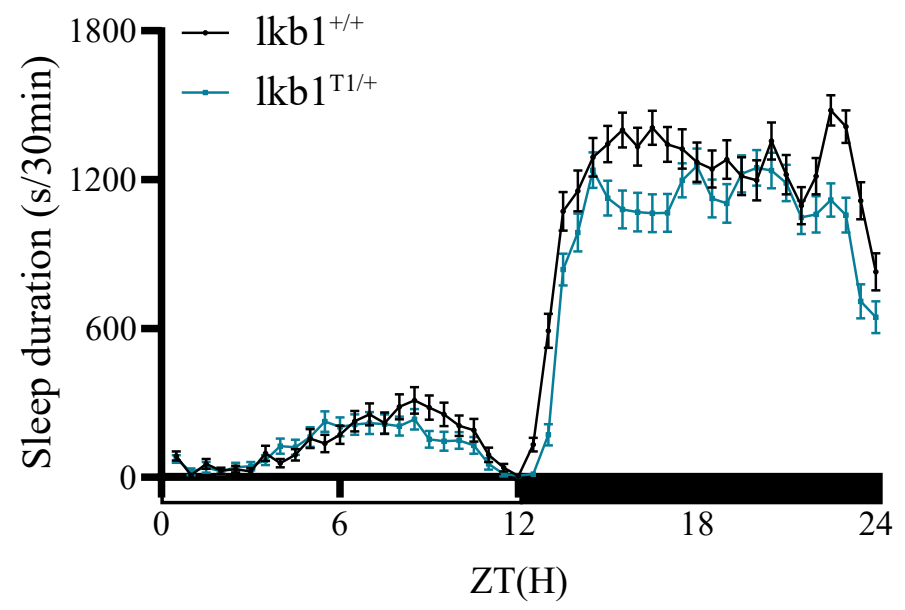

$\mathrm{E}$

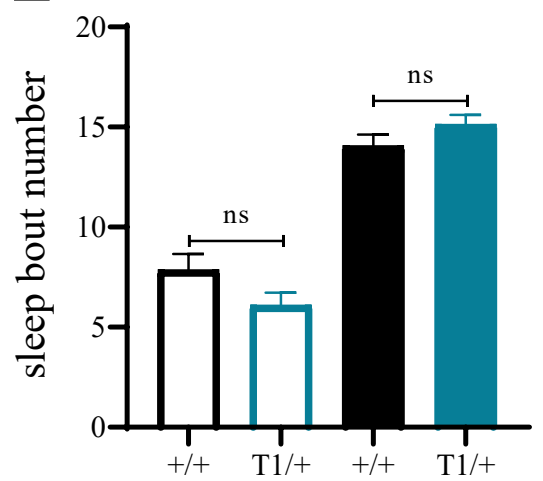

$\mathrm{F}$
D
$\mathrm{B}$

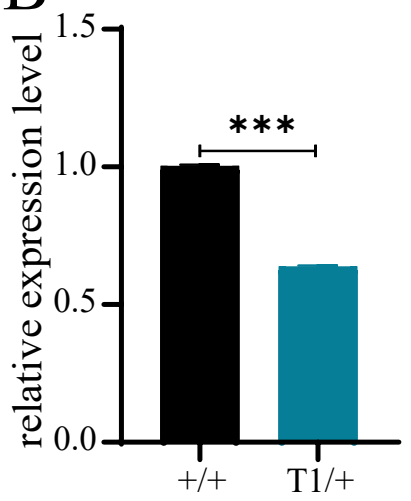

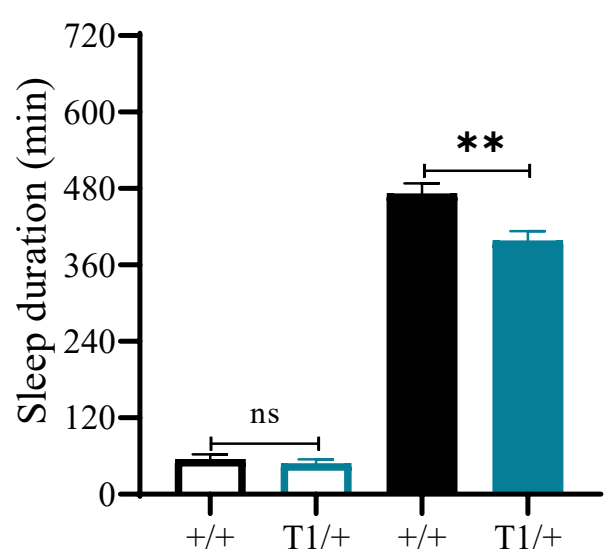

G
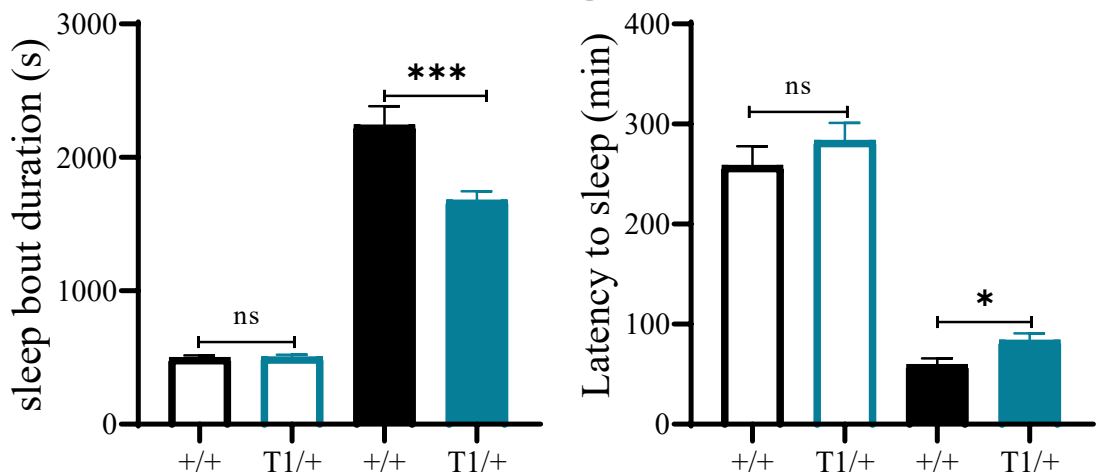
A

lkb1 ${ }^{\mathrm{T} 2}$ Genome

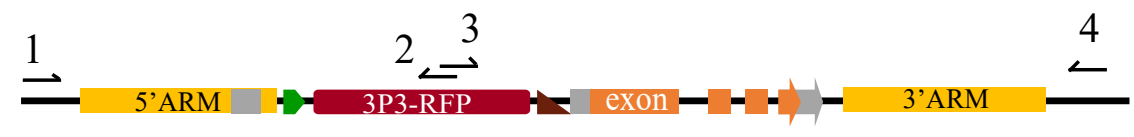

$$
\begin{aligned}
& \triangle \text { attP } \quad \text { LoxP }
\end{aligned}
$$

B

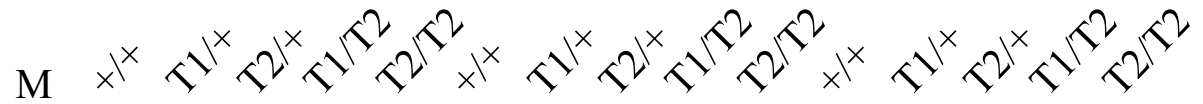

$$
\begin{aligned}
& 1+2 \\
& 3+4 \\
& 1+4
\end{aligned}
$$




\section{Supplementary Figure3}

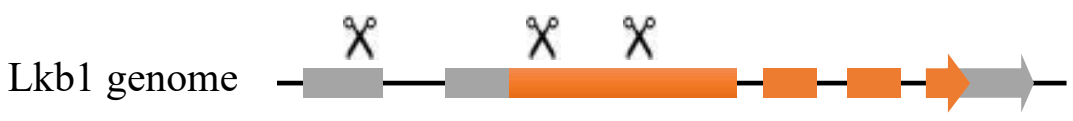

$X$ sgRNA 
Supplementary Figure4

A

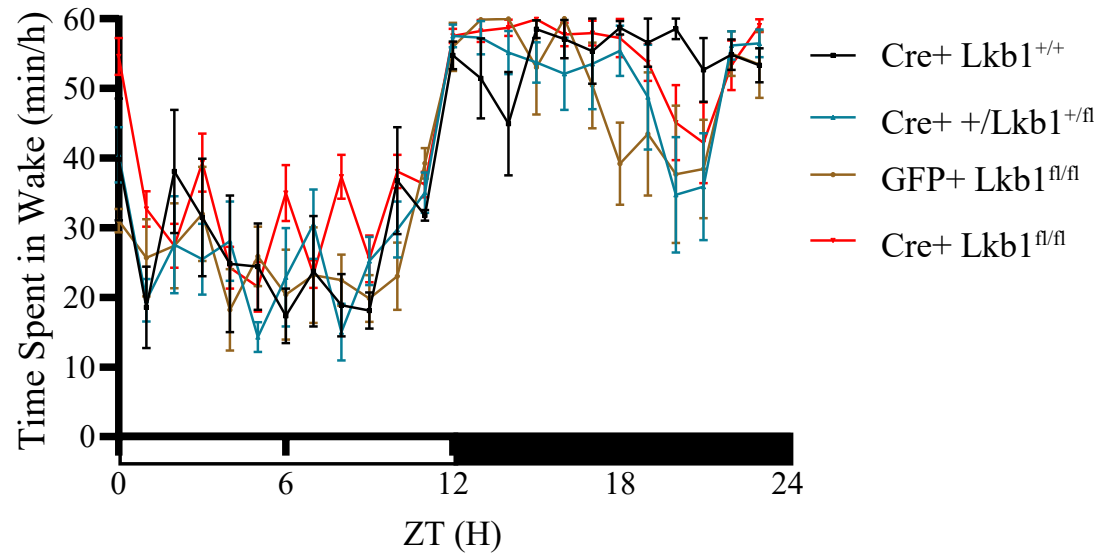

B
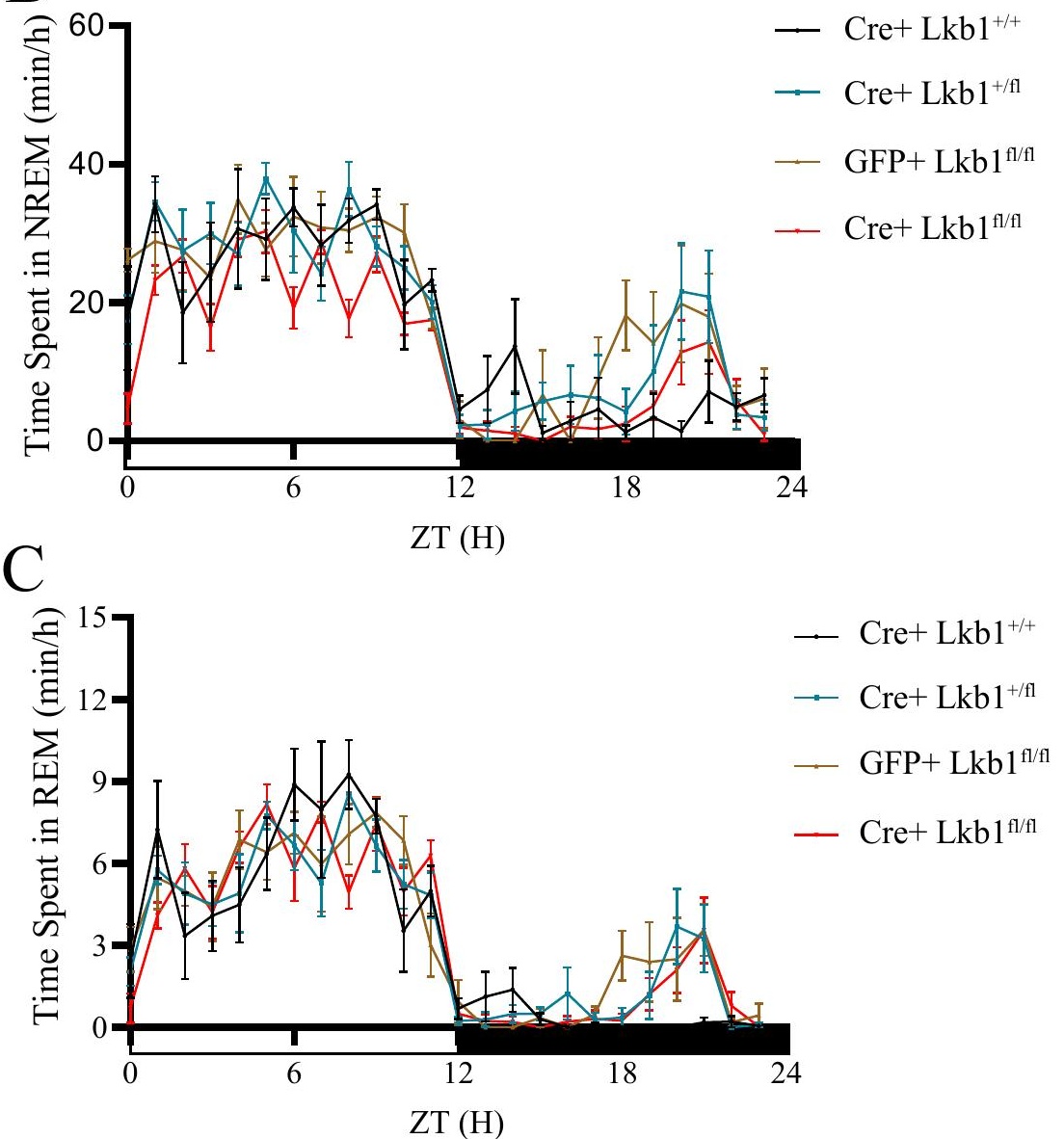

- $\mathrm{Cre}+\mathrm{Lkb}^{+/+}$

- Cre $+\mathrm{Lkbl}^{+/ f l}$

- GFP+ $\mathrm{Lkb}^{\mathrm{fl} / \mathrm{fl}}$

- Cre $+\mathrm{Lkb}^{\mathrm{fl} / \mathrm{fl}}$

24

C 
Supplementary Figure5

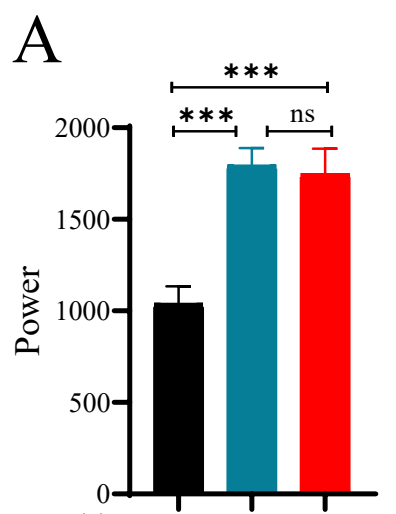

$\mathrm{Lkb} 1+++\mathrm{T} 2 /+\mathrm{T} 2 / \mathrm{T} 2$

B

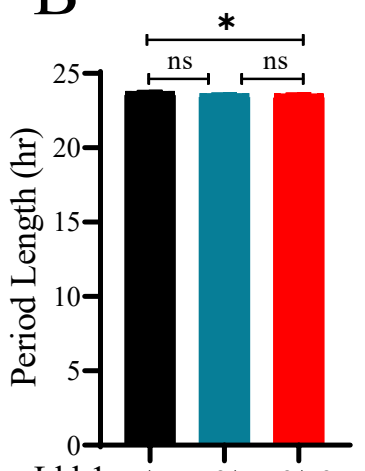

Lkb1 +/+ T2/+ T2/T2

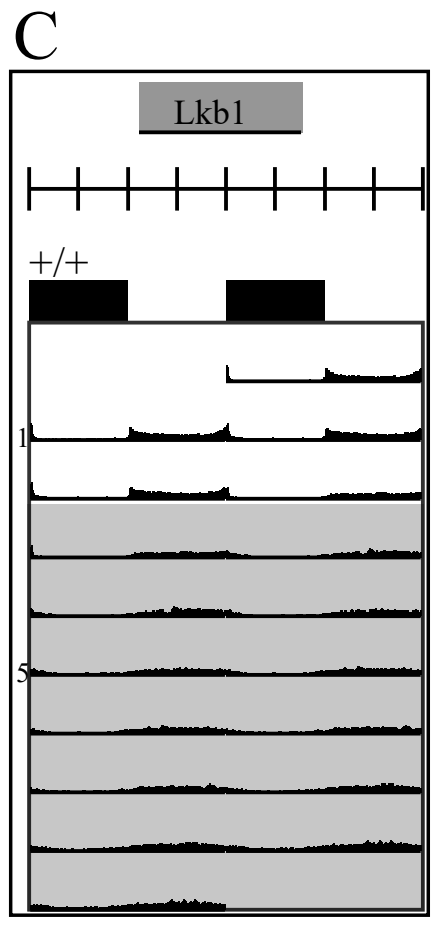

D

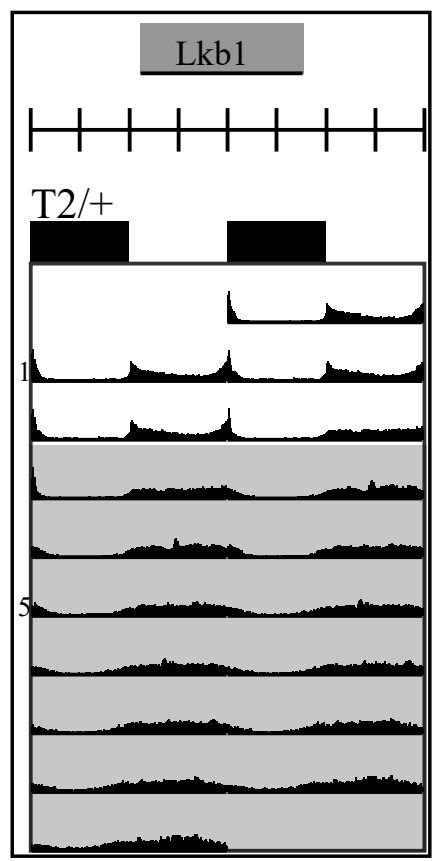

E

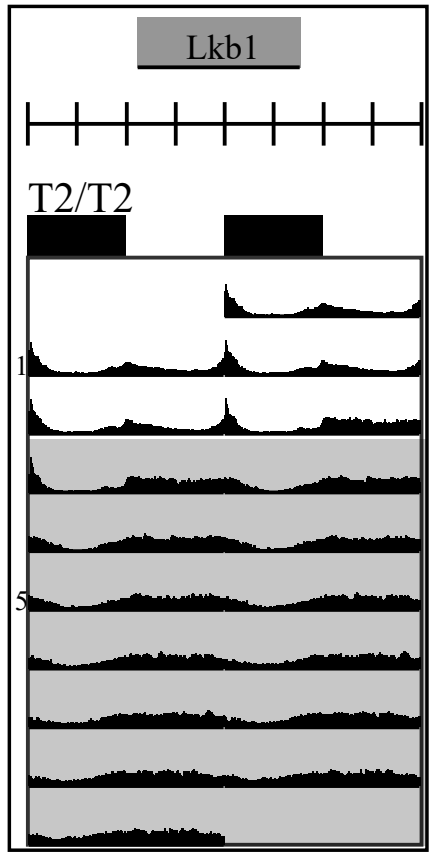

